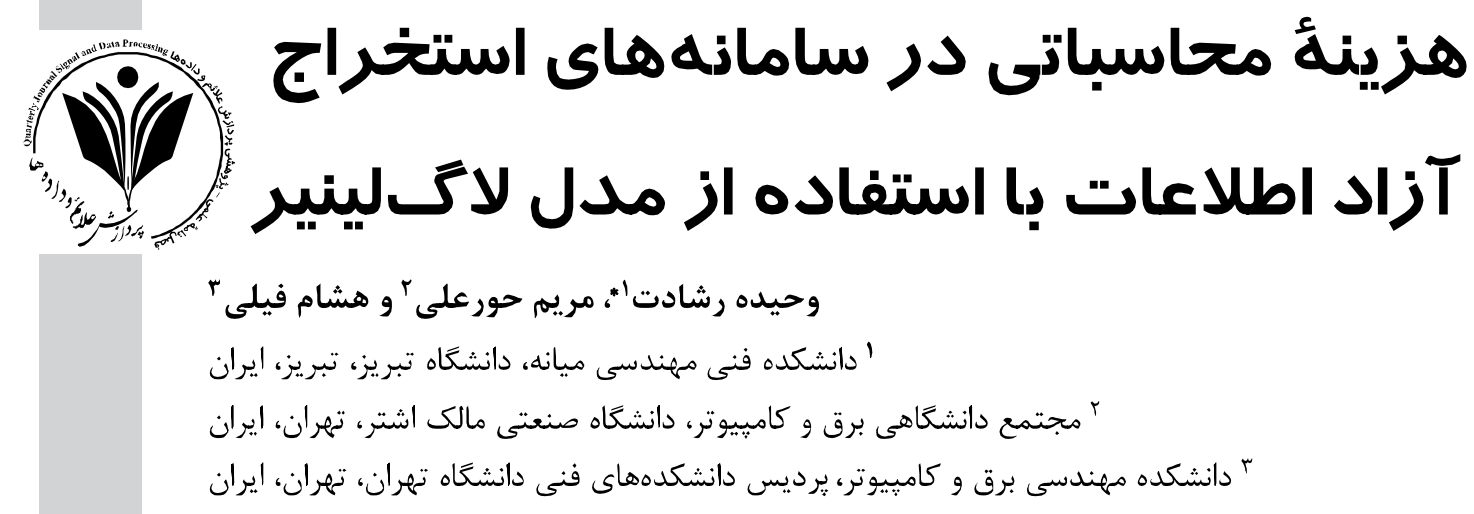

جكبر:

استخراج اطلاعات شامل توسعة الكوريتمهايى است كه بهصورت خودكار متن غيرساخت يافته را يردازش و پايعاه دادهاى از موجوديتها،

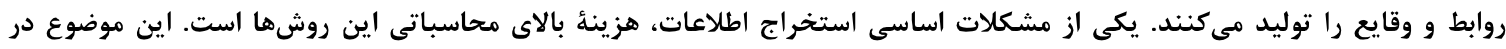

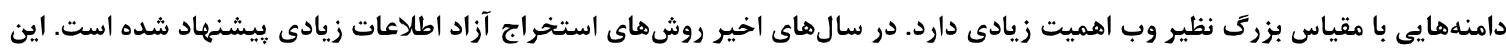

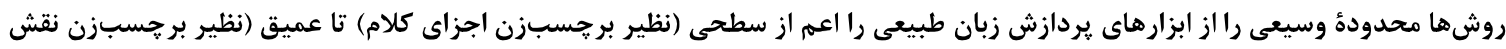

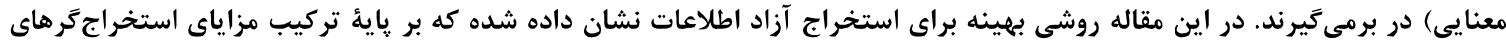

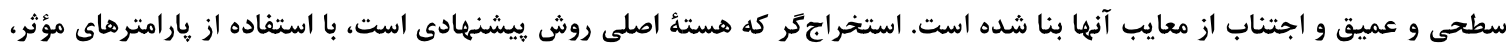

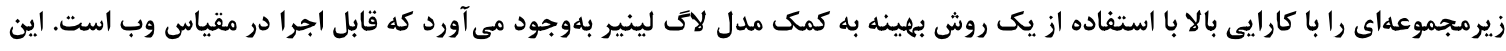

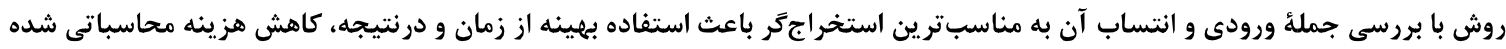

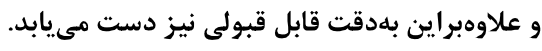

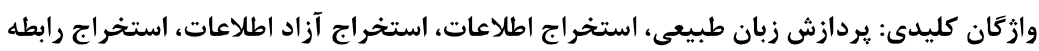

\title{
A New Method for Improving Computational Cost of Open Information Extraction Systems Using Log-Linear Model
}

\author{
Vahideh Reshadat ${ }^{1 *}$, Maryam Hourali ${ }^{2}$ \& Heshaam Faili ${ }^{3}$ \\ ${ }^{1}$ Miyaneh Technical and Engineering Faculty, University of Tabriz, Tabriz, Iran \\ ${ }^{2}$ Malek-Ashtar University of Technology, Tehran, Iran \\ ${ }^{3}$ School of Electrical and Computer Engineering, College of Engineering, University of \\ Tehran, Tehran, Iran
}

\begin{abstract}
Information extraction (IE) is a process of automatically providing a structured representation from an unstructured or semi-structured text. It is a long-standing challenge in natural language processing (NLP) which has been intensified by the increased volume of information and heterogeneity, and non-structured form of it. One of the core information extraction tasks is relation extraction which aims at extracting semantic relations among entities from natural language text. Traditional relation extraction techniques were relationspecific, producing new instances of relations determined a priori. While effective, this model is not applicable in cases where the relations are not defined a priori or when the number of relations is high. Open Relation Extraction (ORE) methods were developed to elicit instances of arbitrary relations while requiring fewer training examples. Since ORE systems are employed by the applications depended on large-scale relation
\end{abstract}

* Corresponding author * نويسندة عهدهدار مكاتبات 
extraction, high performance and low computational cost are major requirements for ORE methods. This is particularly important in the large scales such as the Web. Many OIE systems have been proposed in recent years. These approaches range from shallow (such as part-of-speech tagging) to deep (such as semantic role labeling), therefore they differ in their performance level and computational cost.

In this paper, we use the state-of-the-art shallow NLP tools to extract instances of relations. A supervised loglinear model for OIE is presented which is based on using advantages of shallow NLP tools, as they are fast and lead to a low computational time. Extractor which is the main core of proposed approach integrates a high performance subset of the shallow NLP tools with the strength of the deep NLP tools by using a supervised log linear model and produces a high performance method that is scalable. This causes efficient use of time and therefore reduces computational cost and increases precision. Proposed approach achieves higher precision and recall than ReVerb, one of the most successful shallow OIE system.

KeyWords: Information Extraction, Open Information Extraction, Relation Extraction, Knowledge Discovery, Fact Extraction

در ابتدا براى مدتهاى طولانى استخراج اطلاعات بهكمى متخصصان حوزه و با روشهاى نيازمند تلاش انسانى، انجام مىشد. اين روشها شامل روشهاى مبتنى بر قالب و وره روشهاى باناظر است كه بهترتيب نوع حفرههاى قالب و رابطه

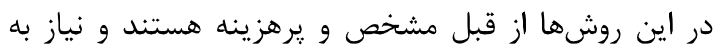
تلاش دستى دارند. در روشهاى نيمهنظارتى نيز با وجود

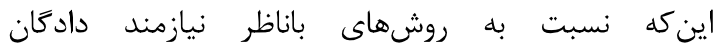

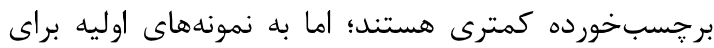

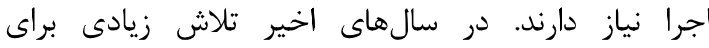
خودكارسازى عمل استخر اج اطلاعات صورت گرفته است و در اين راستا سامانههاى استخراج رابطه بدون ناظر و استخراج آزاد

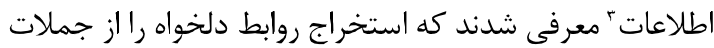

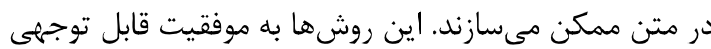

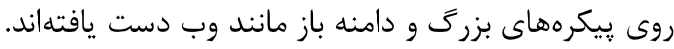

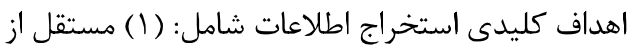

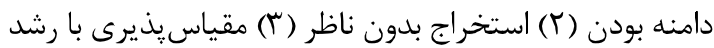

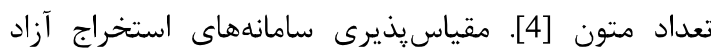

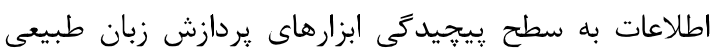

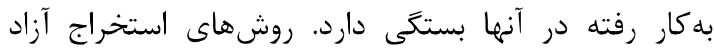
اطلاعات براساس تحليل زبانى استفادهده در استخراج رابطه دئه قابل تقسيم به دو دسته هستند. برخى از سامانهها مانند

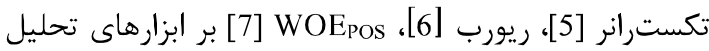

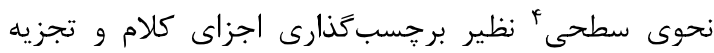

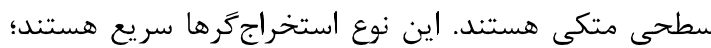

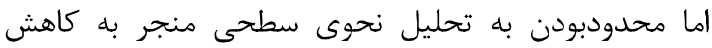
جشمىير معيارهاى كارايى از جمله دقت مىشود. ساير

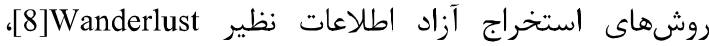

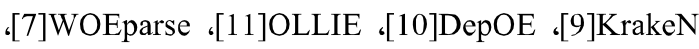
[69]WOEparse و 63]OLLIE،31]DepOE، ،9]KrakeN

${ }^{3}$ Open Information Extraction

${ }^{4}$ Shallow

\section{هol -} امروزه وب جهانگستر بهعلت توزيعشدگى و هزينه يايين توليد محتوا با خالشهاى جديدى از جمله حجم زياد اطلاعات، ناهمگنى و غيرساختاريافتهبودن اطلاعات مواجه شده است. اطلاعات غيرساختيافته، قابل خواندن، سازماندهى و تحليل توسط ماشينها نيستند. براى اينكه بتوان از بين اين حجم انبوه اطلاعات، انسان را در فهرم و يافتن اطلاعات مورد نياز يارى كرد، بايد بتوان متن غيرساختيافته را به به إنهان

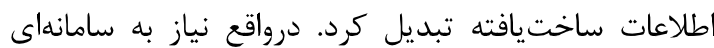
وجود دارد كه بتواند دادهها را بهشكل ساختيافته درآورد.

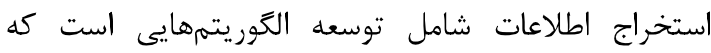
بهصورت خودكار، متن غيرساختيافته را يردازش و يايڤاه دادهاى از موجوديتها، روابط و وقايع را توليد مى كنند. استخر اج روابط'، اصلى ترين بخش استخراج اطلاعات ' بهشمار مىرود و در اين وظيفه روابط معنايى بين موجوديتها در متن كشف مىشود. استخراج اطلاعات نهتنها معناى متن را را آشكار و ما را به هدف نهايي توانايى رايانامهها به فههم متن نزديكتر مىسازد، بلكه مىتواند در كاربردهاى زيادى مانند جستجوى وب، يرسشوياسخ، كاوش متون زيستى (شناسايى روابط بين

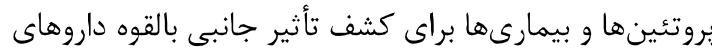
مختلف مفيد است)، كسب خرد جمعى، ساخت هاييًاه دانش

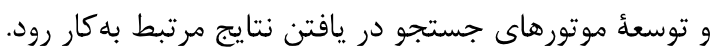

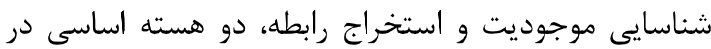
استخراج اطلاعات است [1-3].

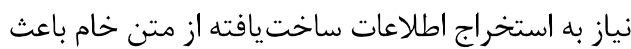
بلوجود آمدن جندين روش از جمله روشهاسى مبتنى بر قالب، مبتنى بر يادكيرى (باناظر، نيمهنظارتى و بدون ناظر) و نيز

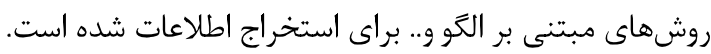

${ }^{1}$ Relation Extraction

${ }^{2}$ Information Extraction 
زمان محاسباتى يايين است. با بهكاربردن استخراجكرهاى عميق براى جملاتى كه استخراجگرهاى سطحى قادر به

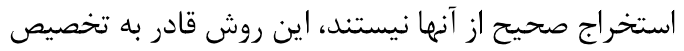

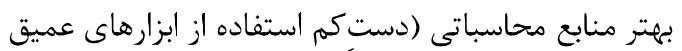

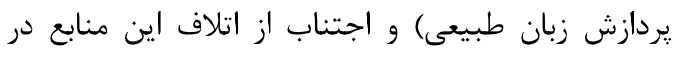
جملاتى است كه احتمال بهبود كارايى در آنها كم است إن.

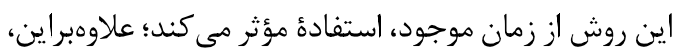

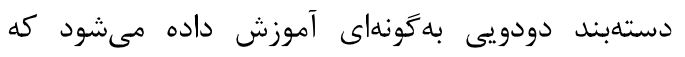

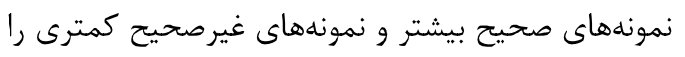

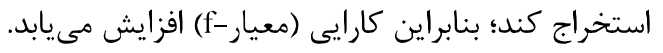

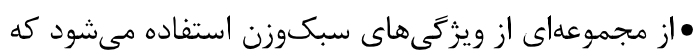

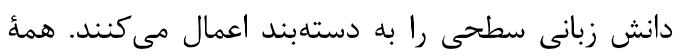

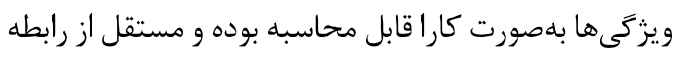

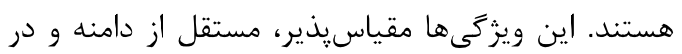

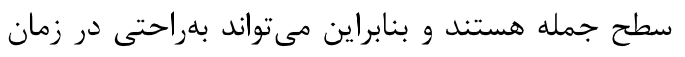

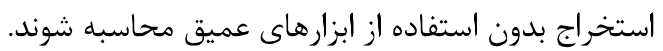

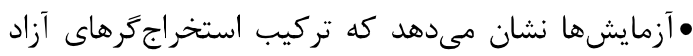
اطلاعات سطحى و عميق و ويداكردن بهترين مسامحه بين

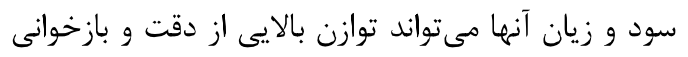

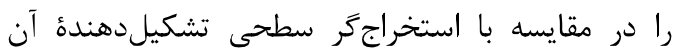

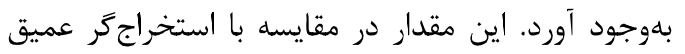

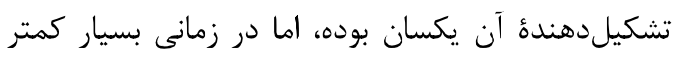

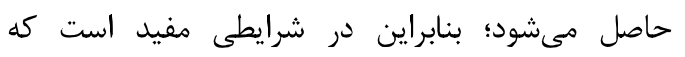

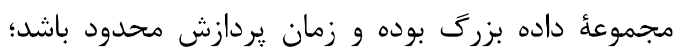
بنابراين اين روش كام اميدبخشى را براى استخراج آزاد رابطه مقياسيذير فراهم مى كند.

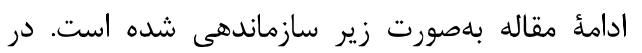

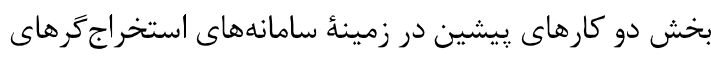
آزاد اطلاعات معرفى و مفهوم جملات دشوار ديش درار در استخراج

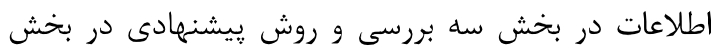

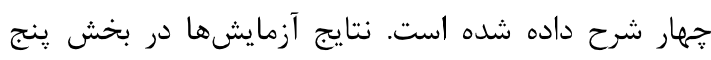

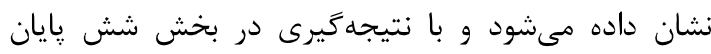

\section{ب- كارهاى مرتبط}

در اين بخش تعدادى از كارهاى مرتبط در استخراج آزاد

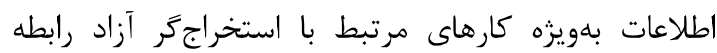

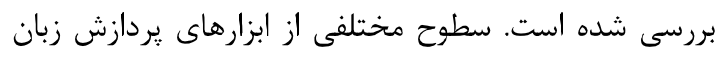

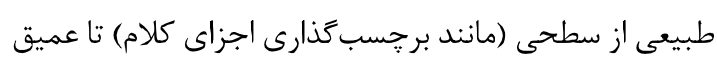

بر تحليلهاى معنايى و نحوى عميق' مانند برحسب تُذارى

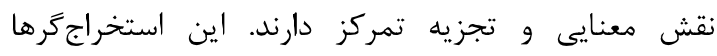

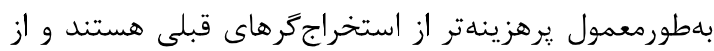

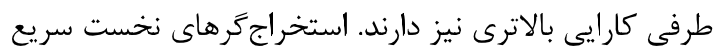

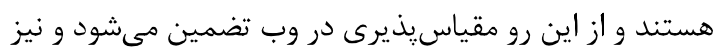

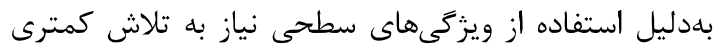

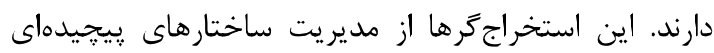

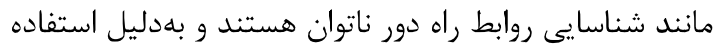

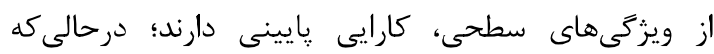

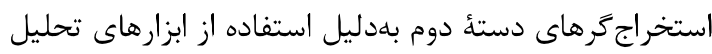

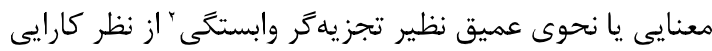

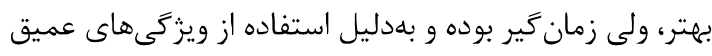
در فرايند استخراج، يرهزينه هستند و مقياسيذيرى بردي بهنسبه קايينترى دارند. با داشتن مزايا و معايب هر كدام از استخراجگرهاى دارن سطحى و عميق، در اين مقاله روشى براى تخمين خودكار

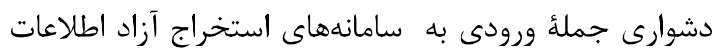

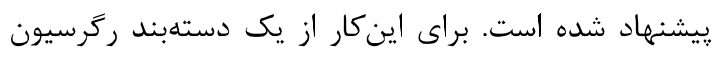

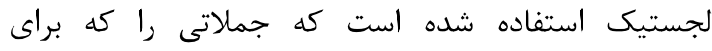

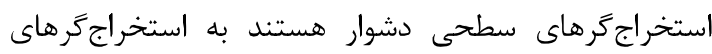

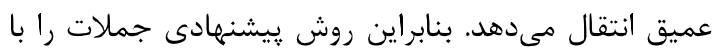

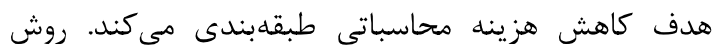

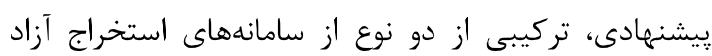

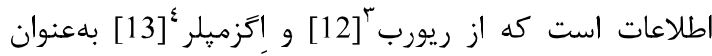

استخر اجكرهاى سطحى و عميق بهترتيب استفاده مى كند.

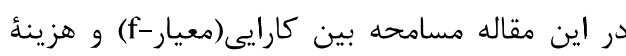

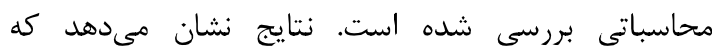

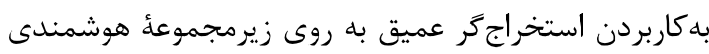

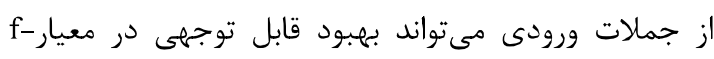

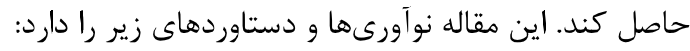

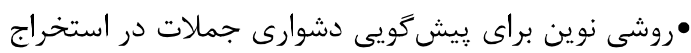

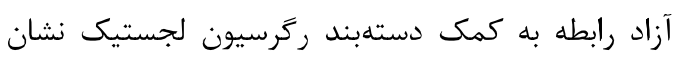

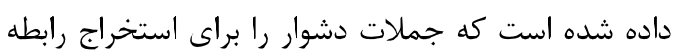

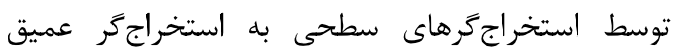

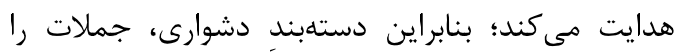

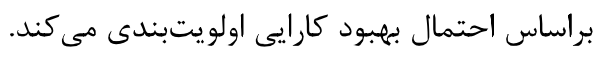

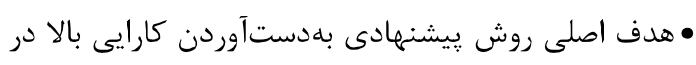

\footnotetext{
${ }^{1}$ Deep

${ }^{2}$ Dependency Parser

${ }^{3}$ ReVerb

${ }^{4}$ Exemplar
} 
جمله وجود داشته باشد، طولانى ترين آنها انتخاب مىشود و

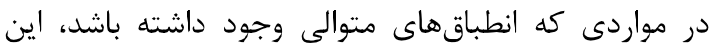

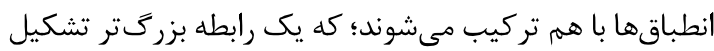
شود. ممكن است، عبارات رابطهاى وجود داشته باشند كه

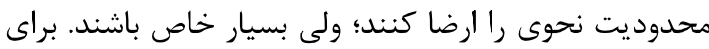

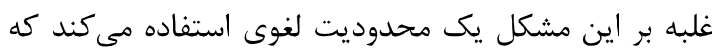
هدفش كاهش تعداد استخراجهاى بسيار خاص است. اين محدوديت بر اين اساس است كه يك عبارت رابطهاي معتبر

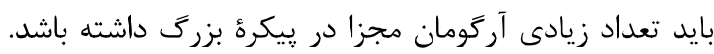
ريورب از يك دستهبند احتمالاتى استفاده مىكند كه براى هر بران خروجى يك ضريب اطمينان تخصيص ميدهند. آزمايشها

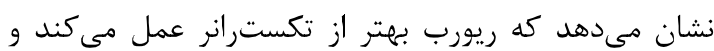

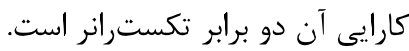

در [15] سامانه SONEX ييشنهاد شده كه توسعهيافتهأ

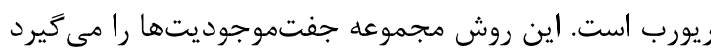
و رابطة مربوطه را توليد مى كند. خروجى اين سامانه جفتهاى مجاى

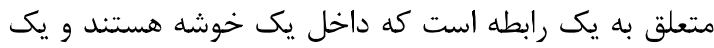

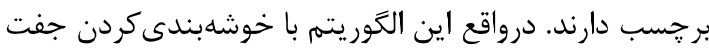

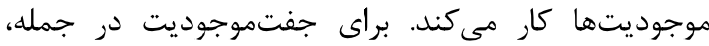

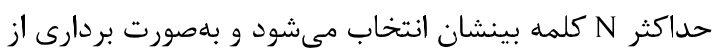

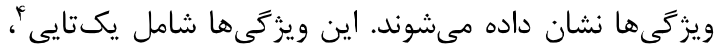

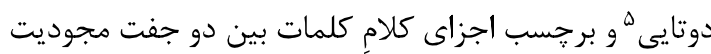

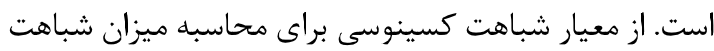
بين بردارها در عمل خوشهبندى استفاده مىشود. در اين مقاله

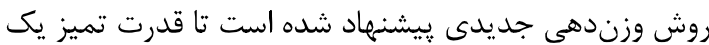

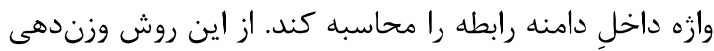
در ساخت ماتريس كلمات استفاده مىشود. براى خوشهبندى

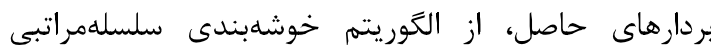
استفاده شده است؛ زيرا نيازى به تعيين تعداد خوشهها ازقبل إنبل

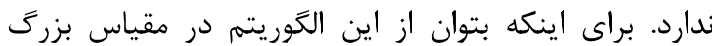

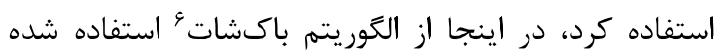

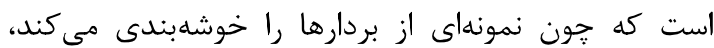

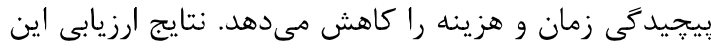

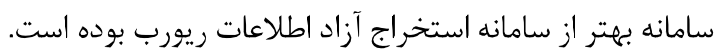

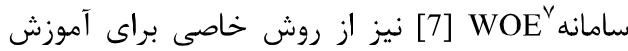

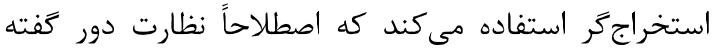
مىشود. در اين سامانه از اطلاعات موجود در جعبه استهاى اطلاعُ

\footnotetext{
${ }^{4}$ unigram

${ }^{5}$ bigram

${ }^{6}$ Buckshot

${ }^{7}$ Wikipedia-based Open Extractor (WOE)

8 infobox
}

(برجسبزن نقش معنايى) در استخراجگرهاى آزاد اطلاعات

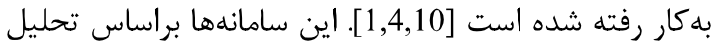
زبانى بهكارفته در عمل استخراج مىتوانند به جند دسته اصلى تقسيم شوند كه در ادامه بررسى شده است.

\section{I- - ر رشهاى استخراج آزاد اطلاعات سطحى}

در اين بخش روشهاى استخراج آزاد اطلاعات سطحى بررسى مىشوند كه بر ابزارهاى سطحى زبان طبيعى تكيه مي ركنند.

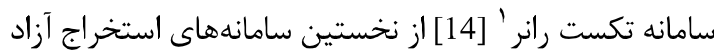

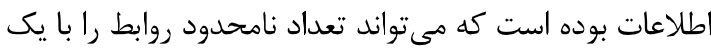
كذر در مقياس وب استخراج كند. اين سامانه مستقل از دامنه

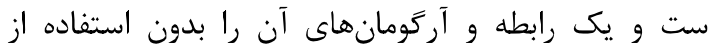

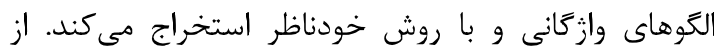

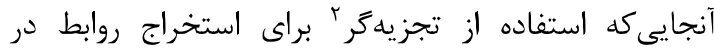

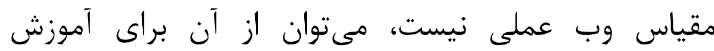

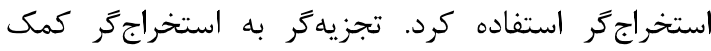

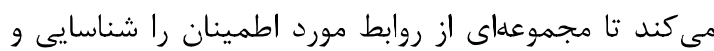
برجسب بزند. براى ايجاد مجموعه آموزشى براى هر جمله رأه

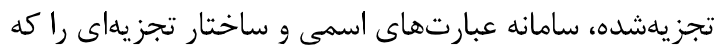
دو موجوديت را بههم وصل مى كند ييدا مى كند و با باعمال محدوديتهايى در صورت برقراربودن محدوديتها (احتمال

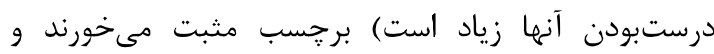

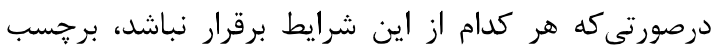

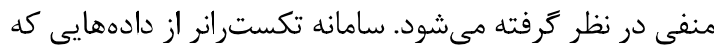

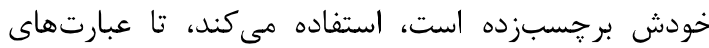

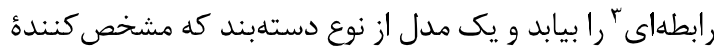
وجود يا عدم وجود رابطه است، توليد مى كند. براى بهره آنيرى

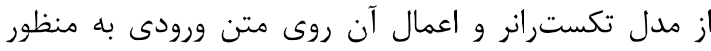

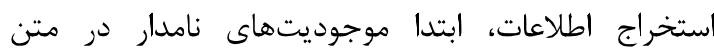
شناسايى و سيس رابطة بين هر دو موجوديت توسط دستدبند آموزش ديده تشخيص داده مىشود.

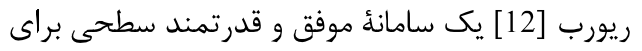
استخراج اطلاعات است. اين سامانه از دنبالهاى از

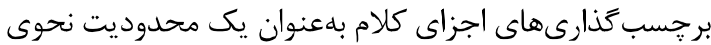

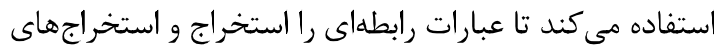

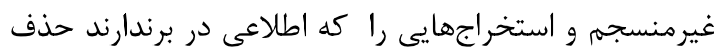
كند. اگر براى يك فعل جند انطباق با قواعد نحوى در يك إنى

${ }^{1}$ TextRunner

${ }^{2}$ Parser

${ }^{3}$ Relational phrase 


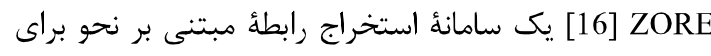

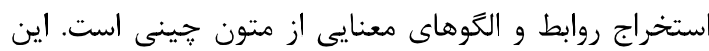

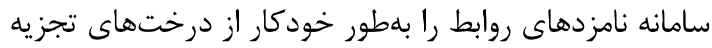

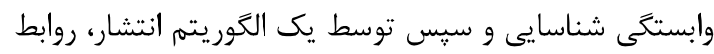
با التوهاى معنايىشان را بلهور تكرارى استخراج مى كند. روش [17] نيز روى استخراج آزاد روابط جينى تمركز دارد.

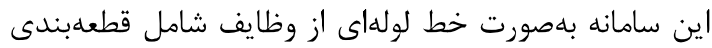
كلمات، برجسبزنى اجزاى كلام و تجزيه است.

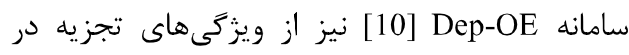

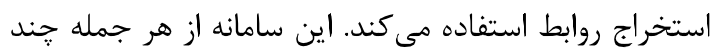
حقيقت در قالب روابط دوتايى استخراج مى كند و به استخراج اطلاعاتى كه با اجزايى غير از فعل بيان مىشود، نيز توجه دارد. همجنين به استخراج خردجمعى از حقايق نيز توجه داشته

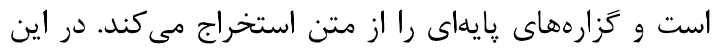

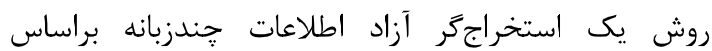

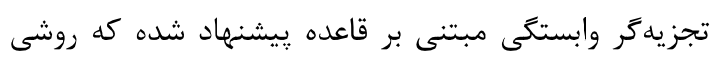
سريع و مقاوم است. اين روش شامل سه مرحله است: هر جمله

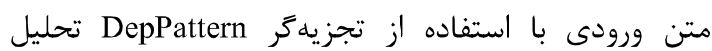

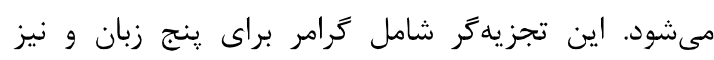

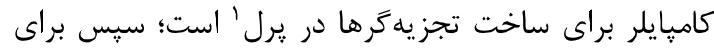

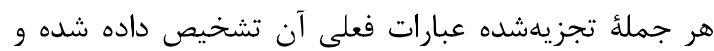
سيس براى هر عبارت اجزاى فعل (شامل فاعل، مفعول

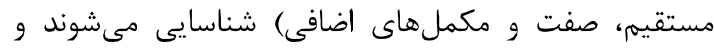
درنهايت مجموعهاى از قوانين به اجزاى عبارت كه ده در مرحلئ

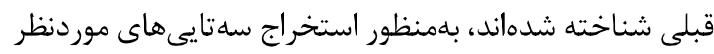

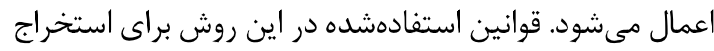

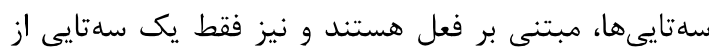

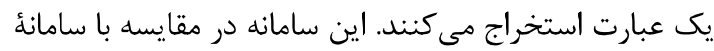
استخر اج آزاد اطلاعات ريورب دقت و نيز معيار F- بالاترى دارد.

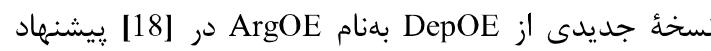

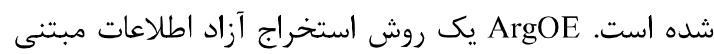

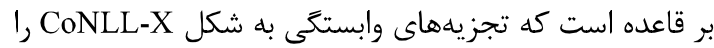

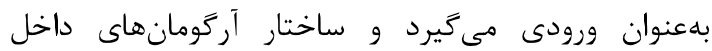

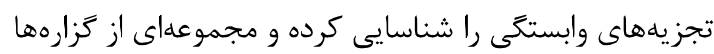
را از ساختار آركومان استخراج مى كند. اين روش نيازى به إنهائ

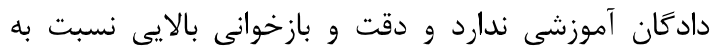

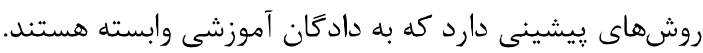

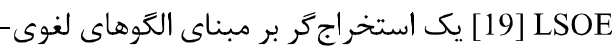

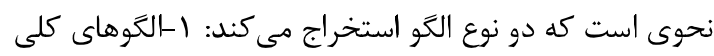

ويكى يديا استفاده مىشود. هر اطلاع يك رابطهُ دوتايى است

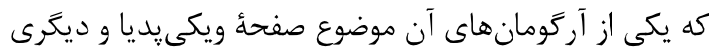

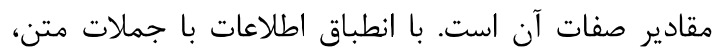

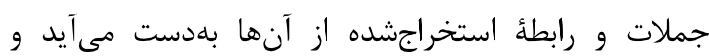

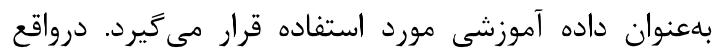

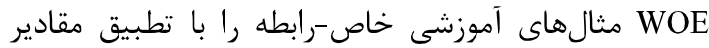

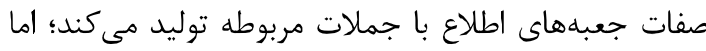

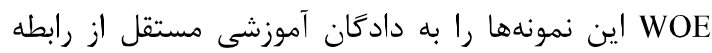

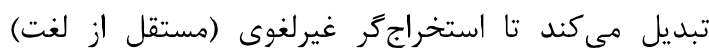
يادگيرى شود. سامانه WOE در دو نسخه متفاوت WOE WOEParse

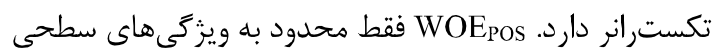
مانند برجسب كذارى اجزاى كلام بوده و همانند تكسترانر

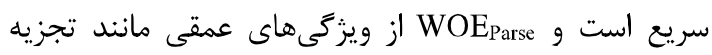

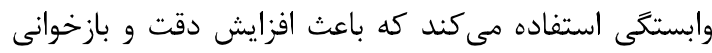

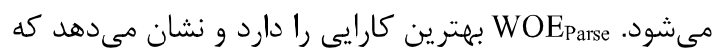
استفاده از ويزگى هاى عميق مانند تجزيه وابستكى مىتواند

كيفيت استخر اج را ارتقا دهد [1] سامانه R2A2 [6] با توسعه سامانٔ ريورب در بخش آنش استخراج آركومانهاى رابطه توليد شده و بسيارى از خطاهاى

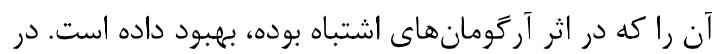

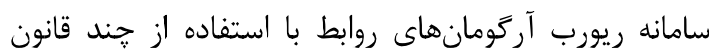

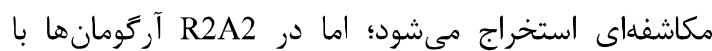
استفاده از دستهبند CRF آموزش داده مىشوند. يادكير آمادي

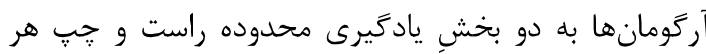

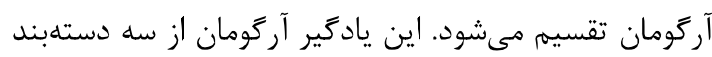

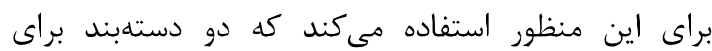

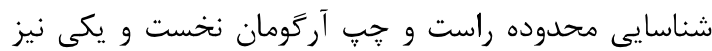

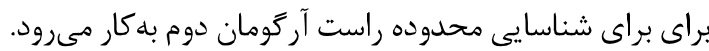

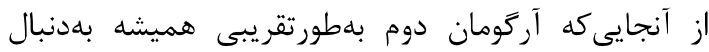

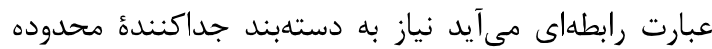

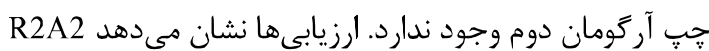

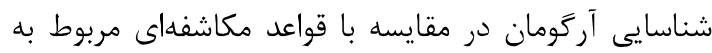

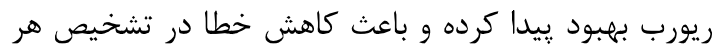
دو آرَومان رابطه شده است.

\section{r-r - - روش هاى استخراج آزاد اطلاعات عميق}

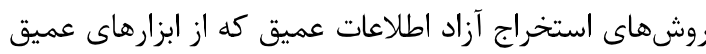

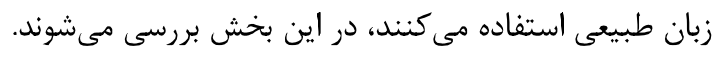


نمودار براى نمودارهاى دقت در اين سامانه حدود 9, 1 تا Y,V برابر در مقايسه با ريورب و woe است.

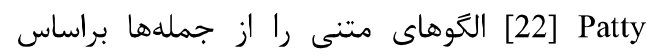
مسيرهاى موجود در درخت تجزيهُ وابستكى بين دو موجوديت راني

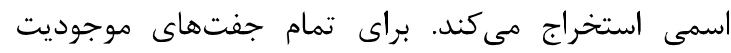
اسمى، patty كوتاهترين مسير را در درخت وابستخى ييدا

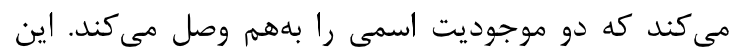

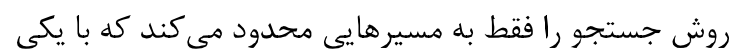
از يالهاى وابستخى خاص شروع مىشود. [4] ClauseIE يك روش مبتنى بر عبارت است كه از ماز روشهاى ديكر از اين جهت متفاوت است كه شناسايى ربـ

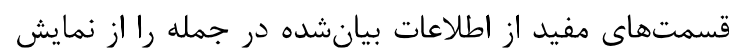

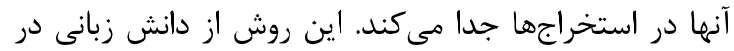

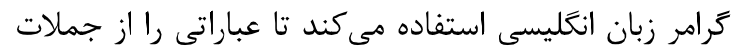

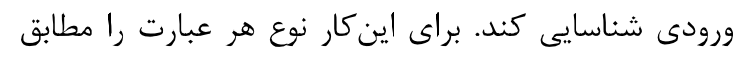

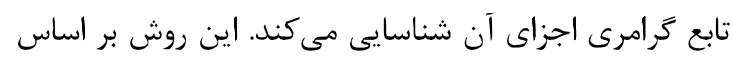

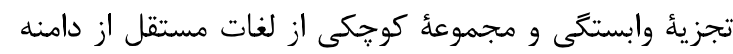

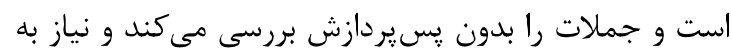

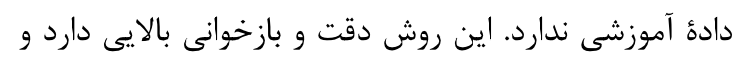
مى مواند براى استخراج روابط n-تايى نيز به كار رود.

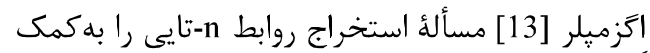
قواعد دستنويس روى درختهاى وابستخى مورد خطاب قرار

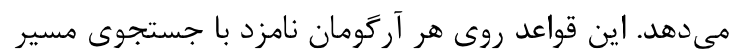

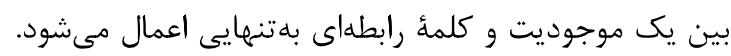
از آنجايى كه هدف دستيابى به دقت بالا و هزينأ محاسباتى

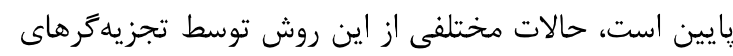

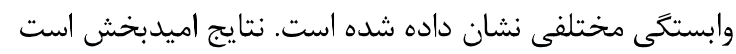

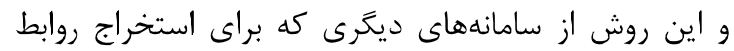

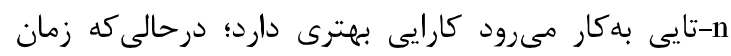
محاسباتى يايينى دارد.

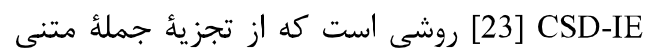

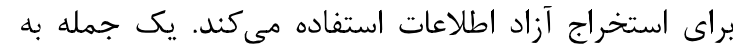
قسمتهايى تجزيه مىشود كه از نظر معنايى بههم وابسته

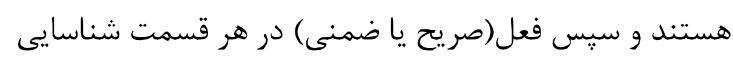

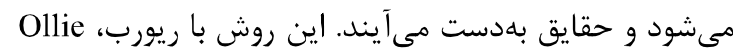

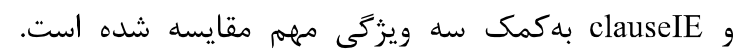

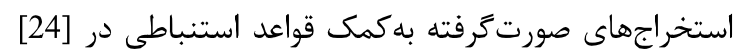

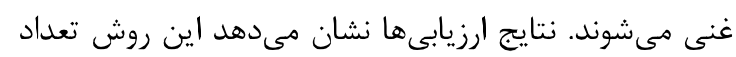

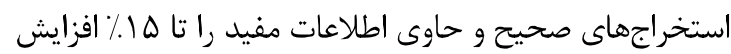

r- قواعدى از روش بيشنهادى در [20]. ايدة اصلى اين است

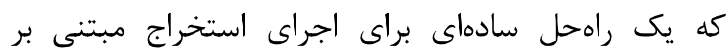

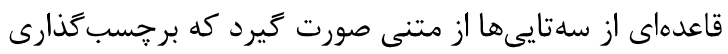

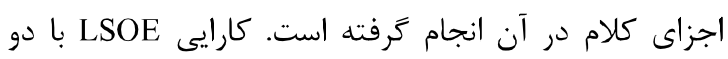

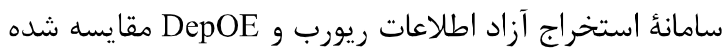

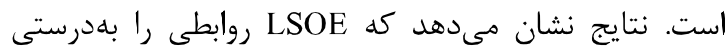

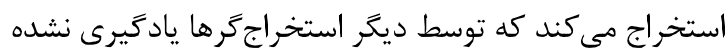

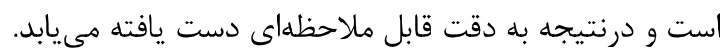

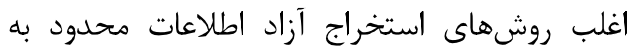

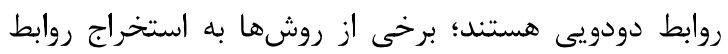

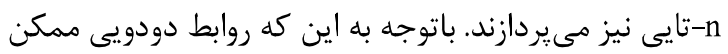

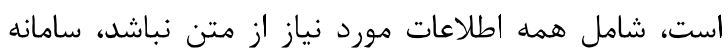
كrakeN

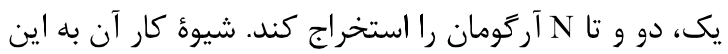

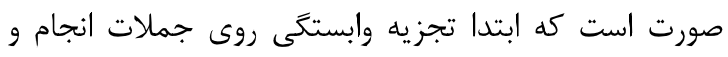

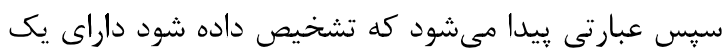
حقيقت است. اين عبارت زنجيرهاى از فعل، بيرايندهها و يا يا بائ

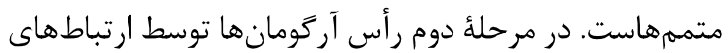

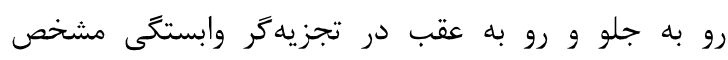

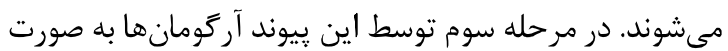

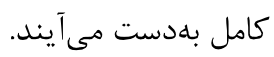
اين سامانه از قواعد مكاشفهاى استفاده مى كند تا خطر جملاتى را كاهش دهد كه بهاشتباه تجزيه شدهاند. بنابراين از

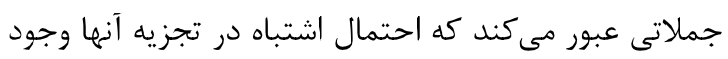

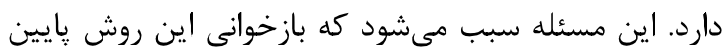

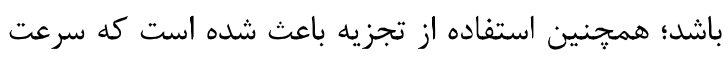

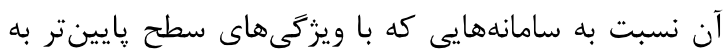
استخراج اطلاعات دودويى مىيردازند، يايينتر باشد.

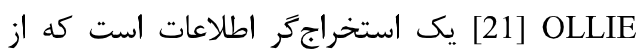

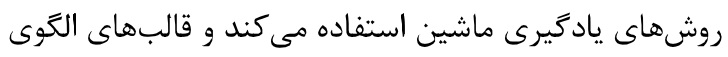

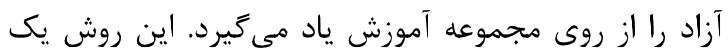

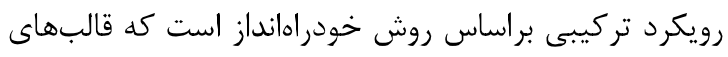

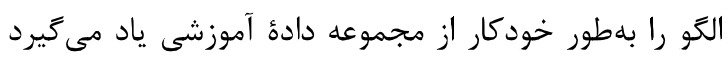
كه از روابط استخراجشده توسط ريورب استفاده ميىكند.

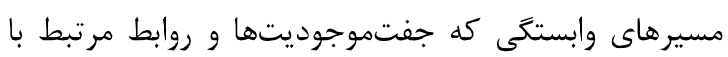

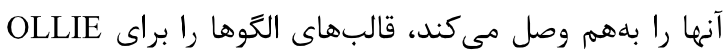

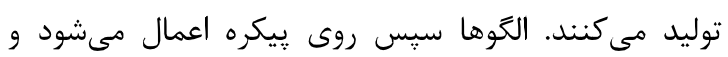

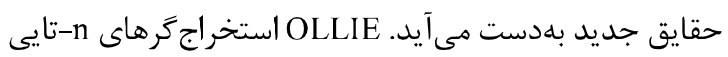

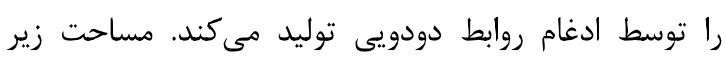


نقش معنايى استفاده شده است. قدرت و ضعف استخر اجرَرها

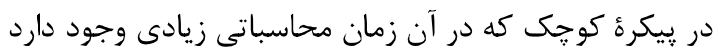

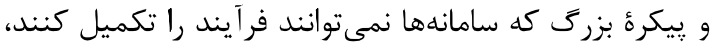

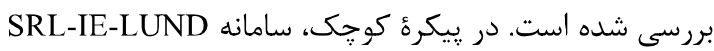
بالاترين دقت و SRL-IE-UIUC بالاترين بازخوانى و بالاترين ا دارد. با تغيير در خروجى اين روش دو سامانه PRECHYBRID و بهوجود آمده است. درصورتى كه اجتماع خروجى سامانههاى مبتنى بر برجسب تذار نقش معنايى و زيرمجموعهاى از تكسترانر كه

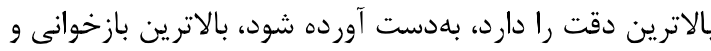
شاخص-F- بهدست مى آيد. زيرمجموعهاى از تكسترانر كه

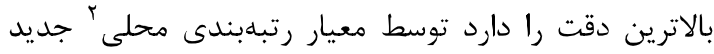

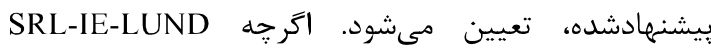
بالاترين دقت را دارد، شرايطى وجود دارد كه تحت آن شرايط

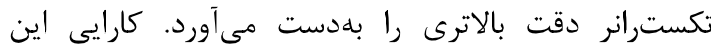

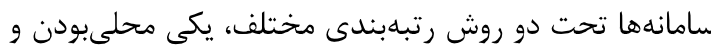

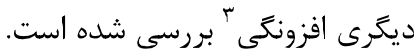

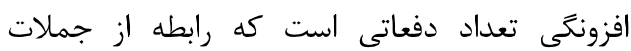
مختلف استخراج مىشود. نتايج رتبهبندى برحسب افزونكي تعني

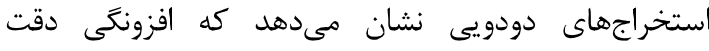

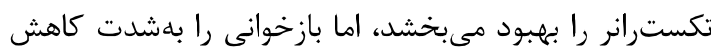
مىدهد. براى پيكرههاى با افزونكى بالا تكسترانر الكوريتم إنى

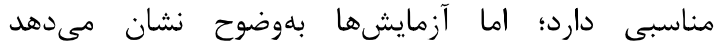
استخراجهاى با فراوانى افزونكى بالا در مقياس وب ماردان محدود

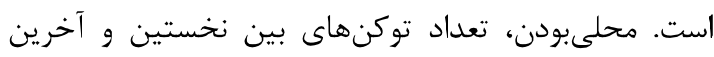

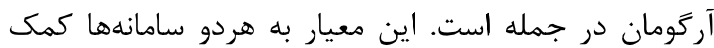
مى كند دقت بالاترى در بازخوانى بالاترى نسبت به به بازخوانى إنى

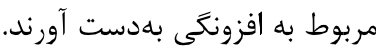

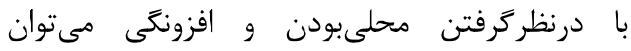
زيرمجموعهاى از تكسترانر كه بالاترين دقت را دارد، بهدست

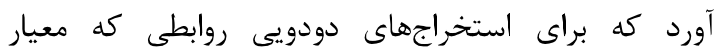

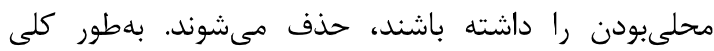

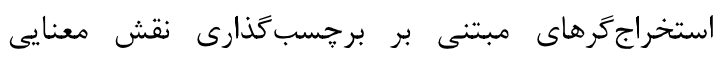

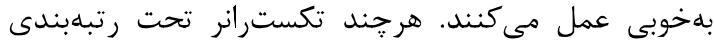

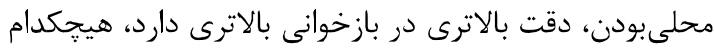

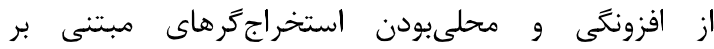

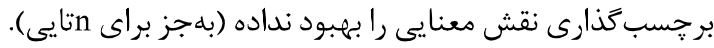

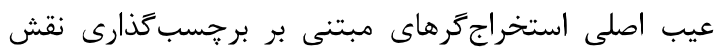

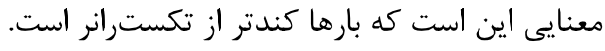

${ }^{2}$ locality

${ }^{3}$ redundancy
مىدهد كه اين كار را با كاهش استخراجهاى غيرمفيد انجام مى دهد. [25] R-OpenIE يك روش استخراج آزاد اطلاعات مبتنى بر قاعده است كه از يك مبدل وضعيت-متناهى إنى

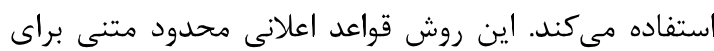
توليد الكوهاى استخراج رابطه تعريف مى كند و از مدل مبدل فئل فئل وضعيت-متناهى آبشارى براى تطبيق تايلهاى رابطهاى رايط

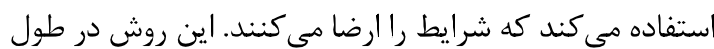
فرايند تطبيق مبدل وضعيت-متناهى آبشارى، براى هر

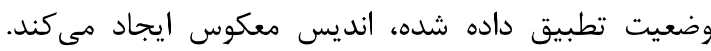

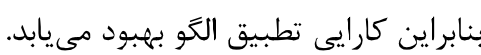
روش TreeKernel [26] نخست بررسى مى كند كه آيا يك رابطه بين يك جفت از موجوديتها در يك جمله وجود

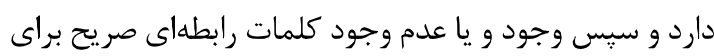
اين جفت را بررسى مىكند. تعدادى مدل ماشين بردار

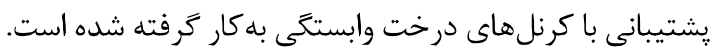
مجموعهاى از الكوهاى نحوى براى توليد روابط نامزد استفاده شده است؛ سيس نمونهاى نامزد با تلفيق همأ جفت موجوديتها با روابط استخراجشده از يك جمله توليد

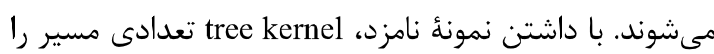
با به كاربردن درخت وابستكى استخراج مى كند. يكى دستهبند ندامند

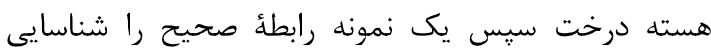

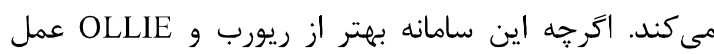
مى كند، اما به زمان محاسباتى بالايى نياز دارد.

\section{ץ-r- روش هاى استخراج آزاد اطلاعات تركيبى}

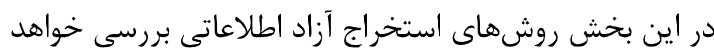
شد كه از تركيب روشهاى سطحى و عميق استفاده مى كنند.

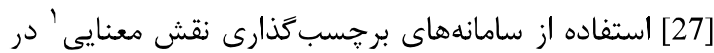

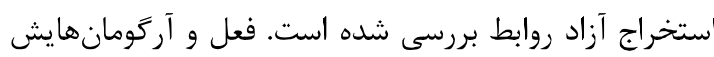

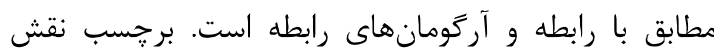

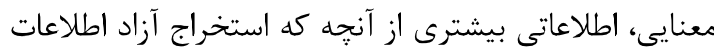

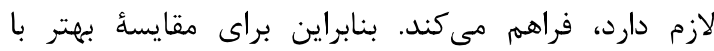

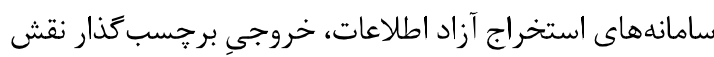
معنايى به استخراجها تبديل مىشود. سامانهٔ برجسب تركذار

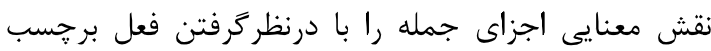

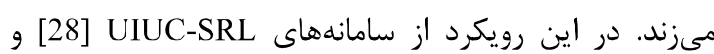

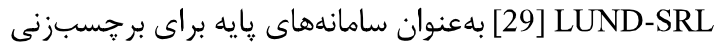

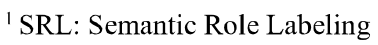


نمىتواند بهكاررود. علاوهبراين، روش يادشده، استخراجزر

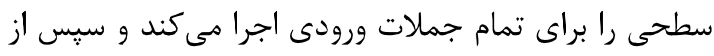

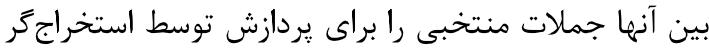

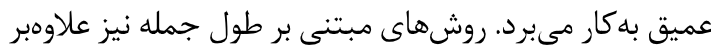

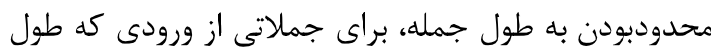

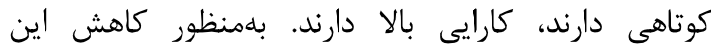
محدوديتها در اين مقاله از يك دستهبند استفاده شده است،

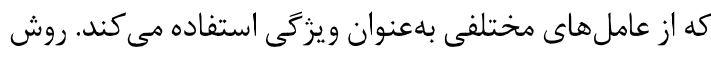

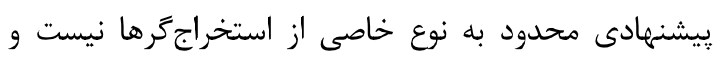

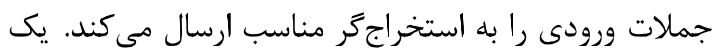
دستهبندى از روشهاى توضيح داده شده، بهاختصار در جدول آدال

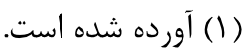

\section{r- جملات دشوار براى سامانههاى استخر اج آزاد اطلاعات}

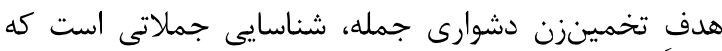

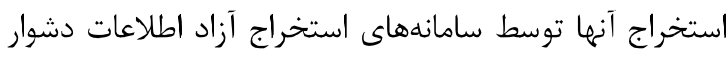
است. تعريف دشوارى جمله در اينجا براساس دو فرضيه است:

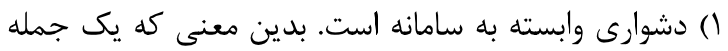
ممكن است براى استخراج توسط يك سامانه استخراجگ دشوار باشد و براى استخراج توسط سامانهُ ديكر آسان/ساده ساه

باشد.

r) دشوارى از كيفيت استخراج ضعيف نمايان مىشود. بهعنوان

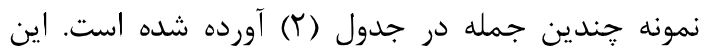

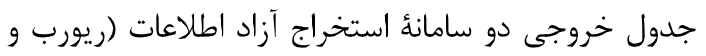

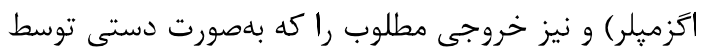

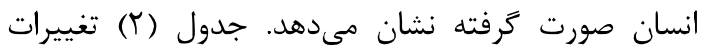

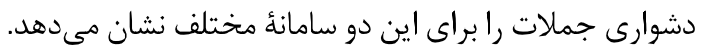

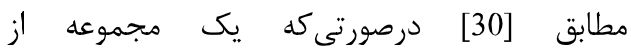

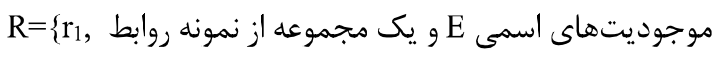

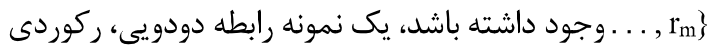

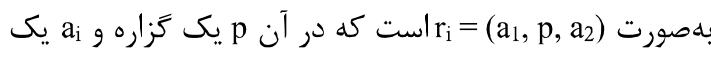

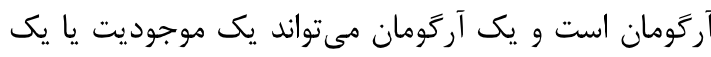

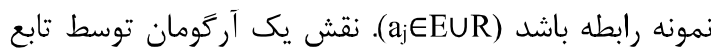
$\rho\left(r_{i}, a_{j}\right) \rightarrow\{$ subject, direct object, prep object\}, مى شود كه در آن مفعول حرف اضافه مى تواند نقشهاى زيادى داشته باشد (براى هر حرف اضافه در زبان يك نقش مر معى تواند
نتايج نشان مىدهد، استخراجكرهاى مبتنى بر برجسب گذارى نقش معنايى نسبت به متن وب كه ناخالصى

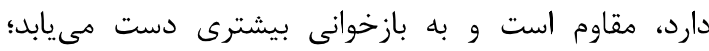

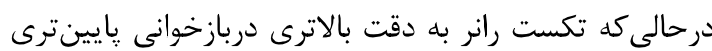

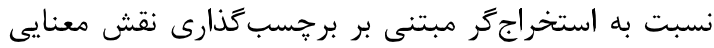

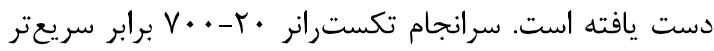

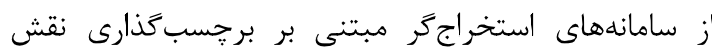
معنايى آزمايش شده است (اين امر بستكى به استفاده از تجزيه وابستخى يا سازهاى دارد). [30] EFFICIENS

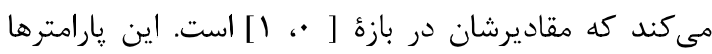

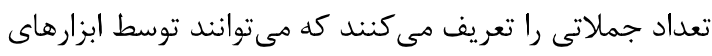

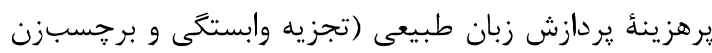

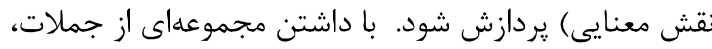

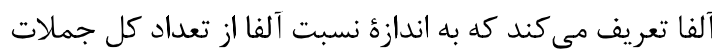
بايد توسط تجزيهَ وابستخى يردازش شود؛ درحالى كه به

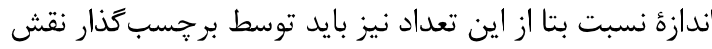

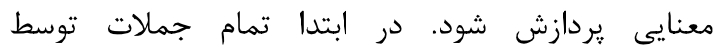

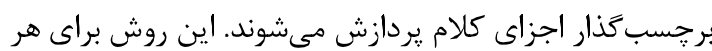

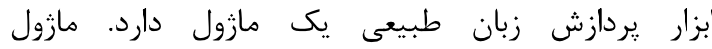

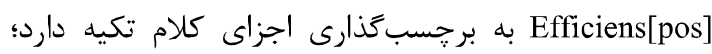
درحالى كه efficiens[srl] و بلهترتيب به تجزيهگ وابستگى و برجسب تانذار نقش معنايى تكيه دارد. هر

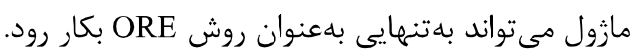
TR-DOE

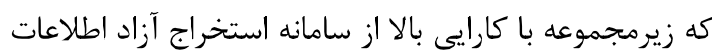

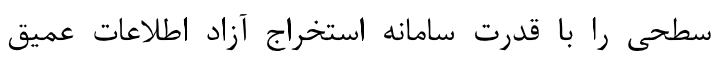

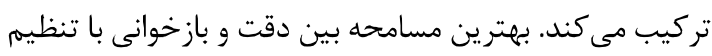
دو يارامتر تركب طول جمله و معيار ضريب اطمينان شناسايى

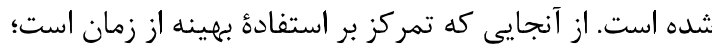

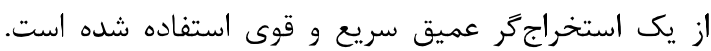

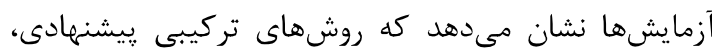

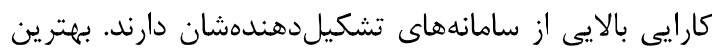

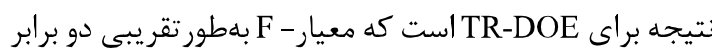
تكسترانر دارد. يكى از معايب عمده اين روشها كمان كمبود

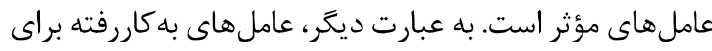

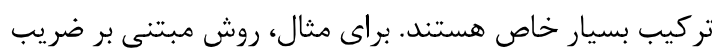
اطمينان براى تركيب روشها، فقط از امتياز اطمينان

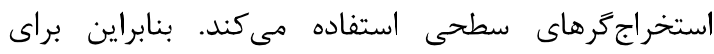
استخراجكرهاى سطحى كه فاقد ضريب اطفي اطمينان هستند، 
(جدول-1): مرور كلى بر روشهاى استخراج آزاد اطلاعات

(Table-1): A review of open information extraction methods

\begin{tabular}{|c|c|c|c|c|}
\hline مدل استخراج (روش توليد) & ورودى مدل & 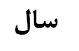 & 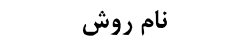 & \\
\hline 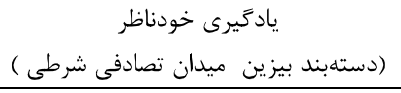 & قواعد مكاشفهاى، ويثَىىهاى سطح بالا & $r \cdots \Lambda$ & TextRunner[5] & \multirow{5}{*}{ روشهاى سطحى } \\
\hline استفاده از عبارت منظم، مبتنى بر قواعد & قيدهاى وازكانى و نحوى، وازْنامهروابط & $r \cdot 11$ & Reverb[6] & \\
\hline الكوريتم HAC و Buckshot & بردار ويزگگىها از محتواى متن بين & t.IT & SONEX[15] & \\
\hline يادگيرى نيمهنظارتى (نظارت دور) و & دادههاى ساختيافته (ويكى پديا) & $r \cdot 1 \cdot$ & WOEPos[7] & \\
\hline استفاده از عبارت منظم و ركرسيون منطقى & قيدهاى وازَّانى و نحوى، وازمنامهى روابط & $r \cdot 11$ & $\mathrm{R} 2 \mathrm{~A} 2[6]$ & \\
\hline الكوريتم انتشار & برجسبزنى اجزاى كلام و تجزيه درختهاى & $r \cdot I f$ & ZORE [16] & \multirow{16}{*}{ روشهاى عميق } \\
\hline بدون يادگيرى، مبتنى بر قواعد & تجزئه وابستخى & $r \cdot I r$ & Dep-OE [10] & \\
\hline بر مبناى الكوهاى لغوى-نحوى & متونى با برجسب اجزاى كلام & $r \cdot 1 r$ & LSOE[19] & \\
\hline بدون يادكيرى، مبتنى بر قواعد & قواعد مكاشفهاى و تجزيه وابستكى & $r \cdot i r$ & KrakeN [9] & \\
\hline يادَيرى الكَوها از درخت وابستكى & بر حِسبزنى اجزاى كلام و تجزيه درختهاى & $r \cdot I r$ & OLLIE[11] & \\
\hline بدون يادگيرى، مبتنى بر قواعد مكاشفهاى & تجزئ وابستخى & $r \cdot I r$ & Patty [22] & \\
\hline بدون يادكيرى، مبتنى بر دانش زبانى در & تجزية وابستخى & $r \cdot 1 r$ & ClauseIE [4] & \\
\hline قواعد دستنويس روى درخت وابستَى & تجزية وابستگى & $r \cdot i r$ & Exemplar[13] & \\
\hline $\begin{array}{c}\text { از تجزيلى جملات و اعمال قواعد } \\
\text { استنباطى }\end{array}$ & جملات تجزئه سازهاى شده & $r \cdot 1 r$ & CSD-IE [23] & \\
\hline مبتنى بر قاعده با كمك مبدل وضعيت- & برحسبزنى اجزاى كلام & $r \cdot 19$ & R-OpenIE[25] & \\
\hline الكوهاى نحوى و نيز ماشين بردار پِشتيبانى & تجزيهٔ وابستىى & $r \cdot 1 r$ & TreeKernel[26] & \\
\hline تجزيه وابستگى و برجسبزن نقش معنايى & متونى با برحسب اجزاى كلام & $r \cdot 10$ & EFFICIENS[30] & \\
\hline تركيب با كمك طول جمله و ضريب & متون با برجسب اجزاى كلام و تجزيه & $r \cdot 19$ & TR-DOE[1] & \\
\hline تركيب با كمك طول جمله و ضريب & متون با برجسب اجزاى كلام و تجزيه & $r \cdot 19$ & RV-DOE[1] & \\
\hline بدون يادكيرى، مبتنى بر قواعد دستى & برجسبزنى نقش معنايى & $r \cdot 11$ & RECALLHYBRID [27] & \\
\hline بدون يادكيرى، مبتنى بر قواعد دستى & برجسبزنى نقش معنايى & $r \cdot 11$ & PRECHYBRID[27] & \\
\hline
\end{tabular}

ريورب منجر به استخراج ضعيف در خروجى آن مىشود. در

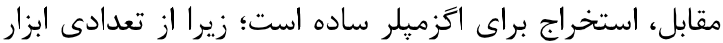

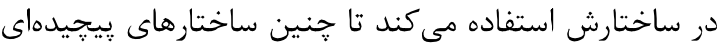
را بلهادگى استخراج كند. دلايل متعددى وجود دارد كه استخراج رابطه را دشوار مىسازد. بيشتر اين دلايل به عمقى كه داجه

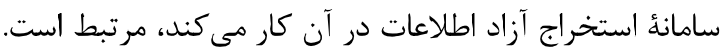

سطرهاى جدول (ז) بر اساس اين تعريف استخراج شدهاند.

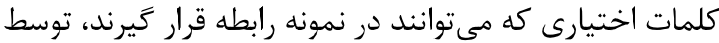

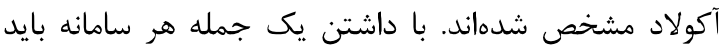

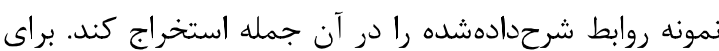
هر جمله در جدول (r) ساختارى نحوى در آن وجود دارد كه آنه

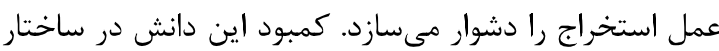




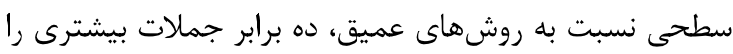

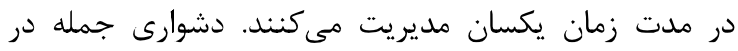

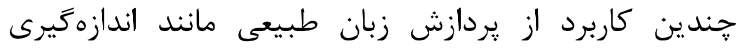

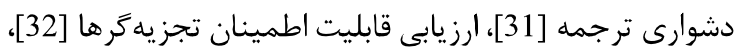

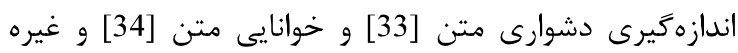

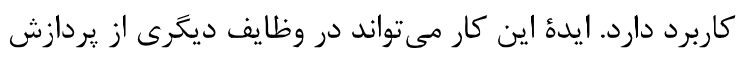

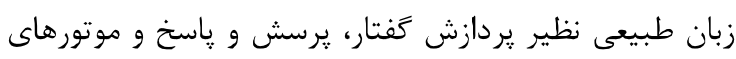

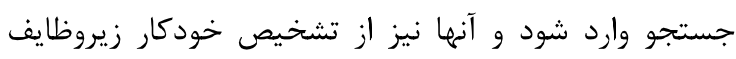

دشوار بهرممند شوند.
از آنجايى كه دشوارى را براساس كيفيت استخراج مدلسازى مى كنيم، مسائلى را در نظر مى دئيريم كه در دراسئ ساختار سامانه

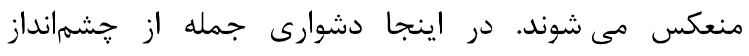

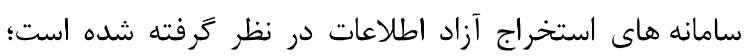

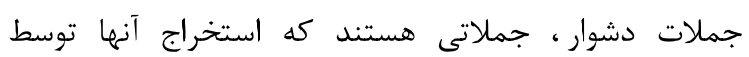

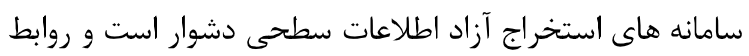

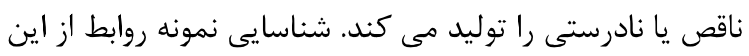

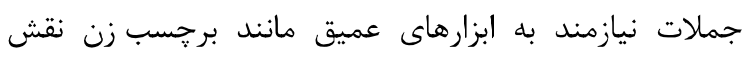

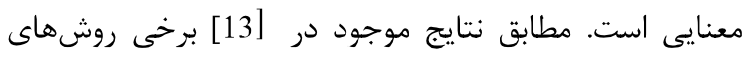

(جدول -Y): جملات دشوار و ساده نمونه

(Table-2): Sample Difficult and easy sentences

\begin{tabular}{|c|c|c|c|}
\hline $\begin{array}{l}\text { Dr. Joan Clos, the executive director of } \\
\text { the United Nations Human Settlements } \\
\text { Programme said urban planning should } \\
\text { be democratic. }\end{array}$ & $\begin{array}{l}\text { Barak Obama is the president of the } \\
\text { United States. }\end{array}$ & $\begin{array}{l}\text { Daniel Jurafsky was recognized by } \\
\text { the MacArthur. }\end{array}$ & جمله \\
\hline $\begin{array}{l}\text { (\{Dr.\} Joan Clos, executive director } \\
\text { \{of\}, the }\} \text { United Nations Human } \\
\text { Settlements Programme) } \\
\text { (\{Dr.\} Joan Clos, said, (urban } \\
\text { planning, should be, democratic)) }\end{array}$ & $\begin{array}{l}\text { (Barak Obama, is }\{\text { the }\} \text { president } \text { of } \\
\text { the }\} \text {, United States) }\end{array}$ & $\begin{array}{c}\text { (MacArthur, recognized, Daniel } \\
\text { Jurafsky) }\end{array}$ & بر خسب انسانى \\
\hline $\begin{array}{l}\text { (the executive director of the United } \\
\text { Nations Human Settlements } \\
\text { Programme, said, urban planning) }\end{array}$ & $\begin{array}{l}\text { (Barak Obama, is, the president of the } \\
\text { United States) }\end{array}$ & - & خروجى ريورب \\
\hline $\begin{array}{l}\text { (Dr. Joan Clos, the executive director, } \\
\text { United Nations Human Settlements } \\
\text { Programme) }\end{array}$ & $\begin{array}{l}\text { (Barak Obama, is president, United } \\
\text { States) }\end{array}$ & $\begin{array}{l}\text { (MacArthur, recognized, Daniel } \\
\text { Jurafsky) }\end{array}$ & خروجى آزيلر \\
\hline
\end{tabular}

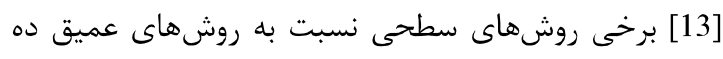

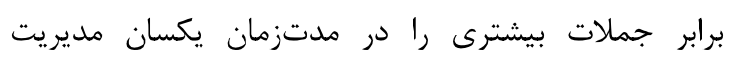

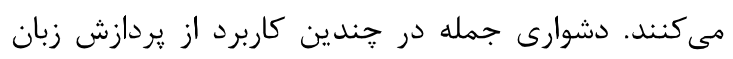

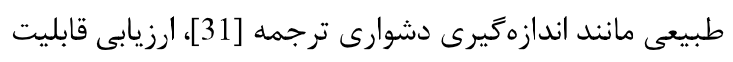

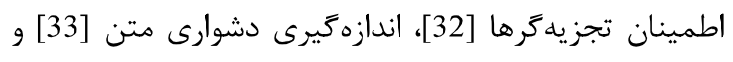

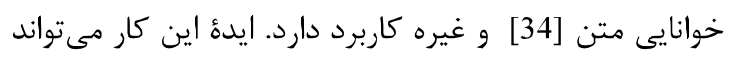

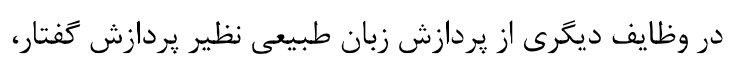

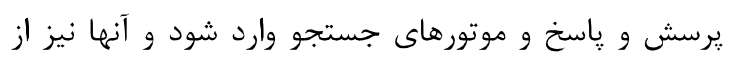
تشخيص خودكار زيروظايف دشوار بهرهمند شوند.

\section{F - روش ييشنهادى براى استخراج آزاد اطلاعات}

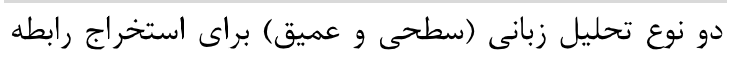

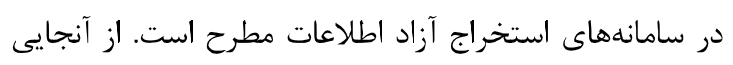

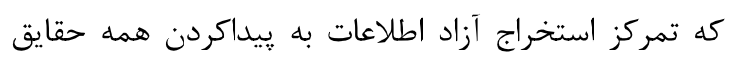

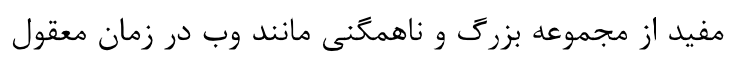

كه عمل استخراج را دشوار مىسازد. كمبود اين دانش در

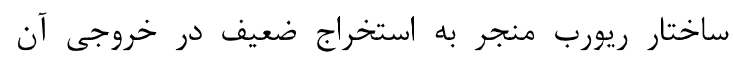

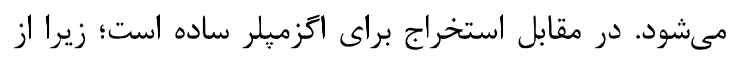

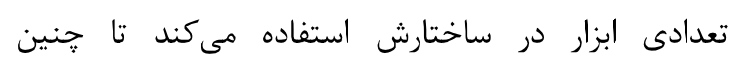

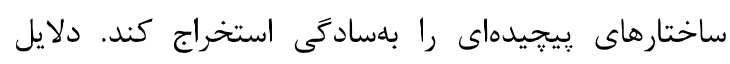

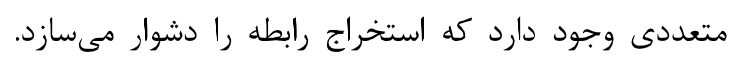

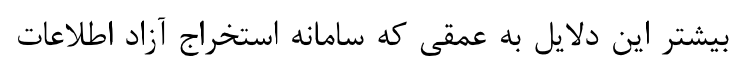

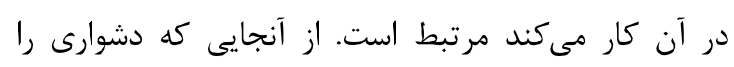

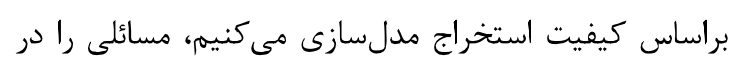

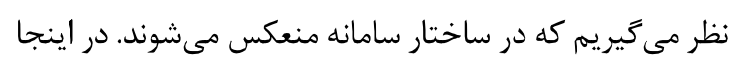

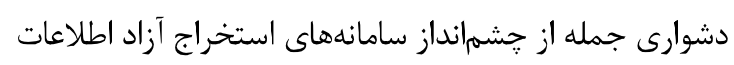

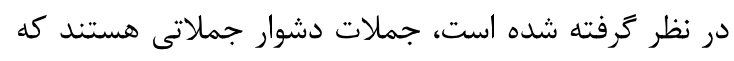

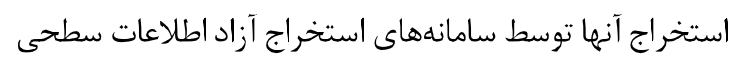

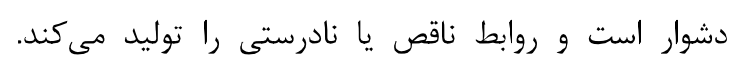

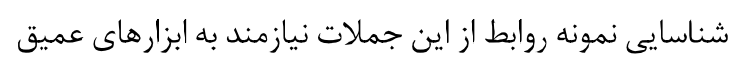

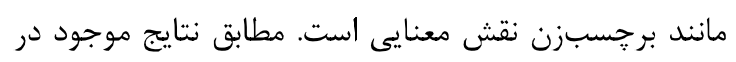


را بهصورت متوالى مىخواند. با داشتن يك جمله، دستهبند

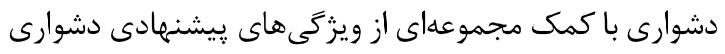
جمله ورودى را براى عمل استخراج بيشبينى مى كند.

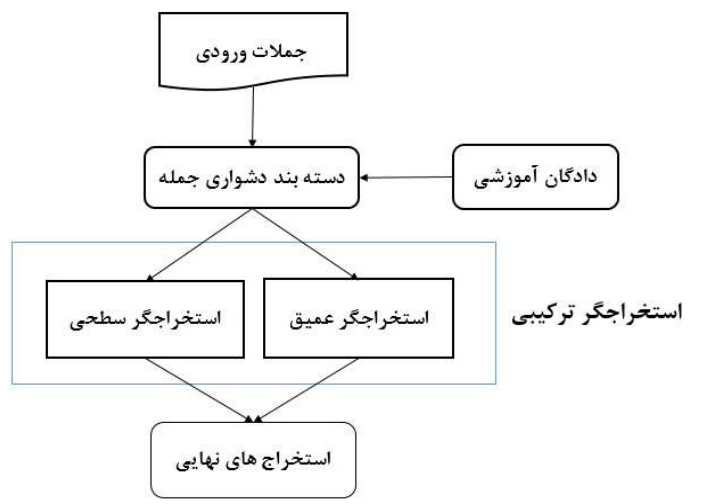

(شكل -1): جار جوب روش پِيشنهادى: دستدبند، بهترين

استخراجگر را بهكار مى

(Figure-1): Framework of proposed approach: Difficulty classifier exploits the best of both the shallow and the deep OIE extractors

به عبارت ديكَر براى هر جمله ورودى دستهبندِ دشوارى، مناسبترين سامانه را براى يردازش آن جمله انتخاب ميكى

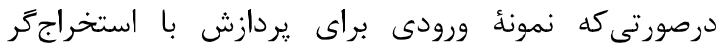

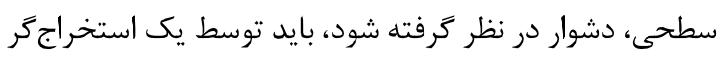

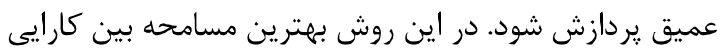
و هزينهُ محاسباتى بهدست آمده است.

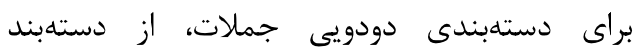

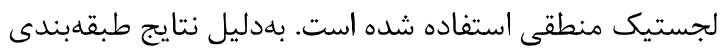

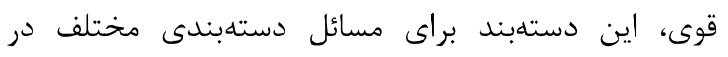

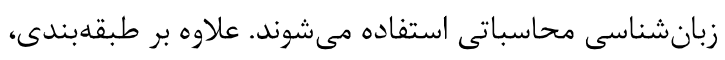

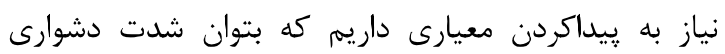
استخراج را تخمين زد. براى اين منظور از امتياز دستهبند ديند بلهنوان معيار دشوارى استفاده مىشود. تخدئ

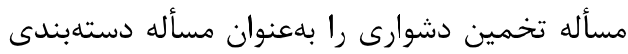

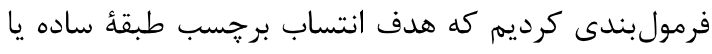

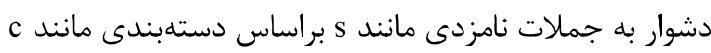

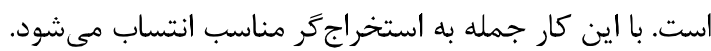

$\mathrm{c}: \mathrm{s} \rightarrow\{$ easy,difficult $\}$

وظيفه دستهبند دشوارى (دستهبند احتمالى ركرسيون

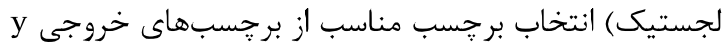

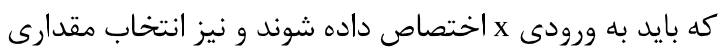

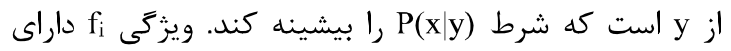

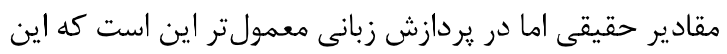

است، روشهايى كه از ابزارهاى عميق يردازش زبان طبيعى

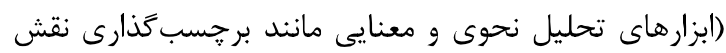

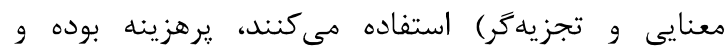

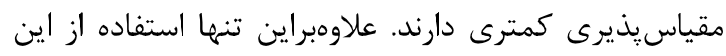

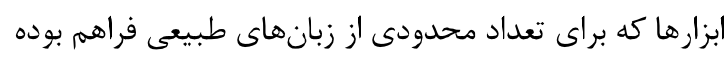

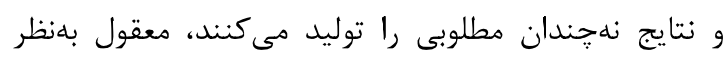
نمىرسد. از طرفى تحليل دستى عميق نيز كارى دئ دشوار،

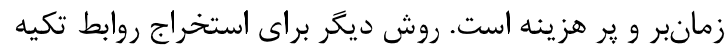

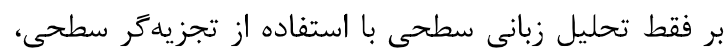

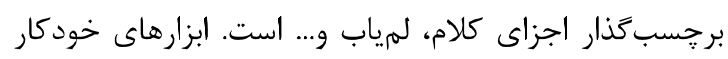

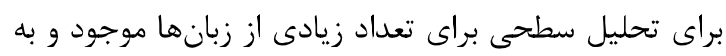

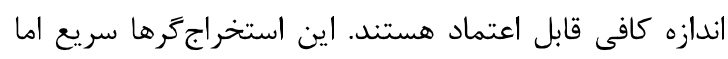

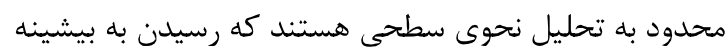

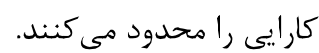

درواقع نياز به سامانهاى است كه استفاده مؤثر از زمان

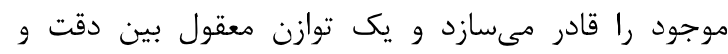

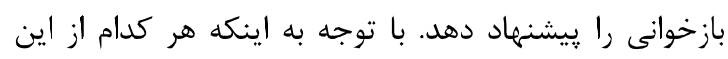

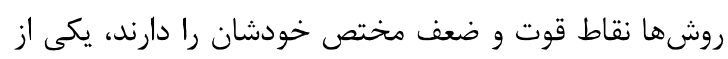

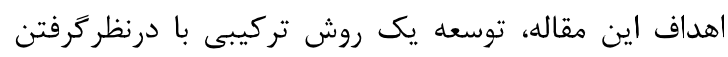

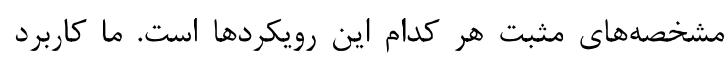

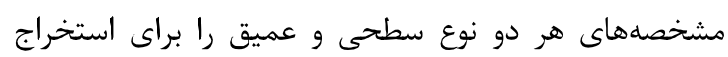

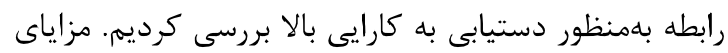

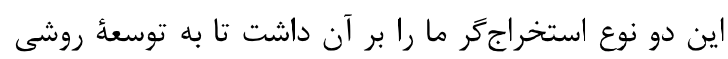

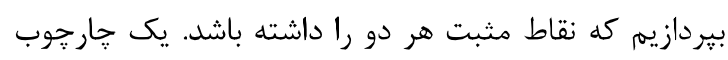

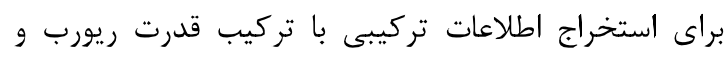

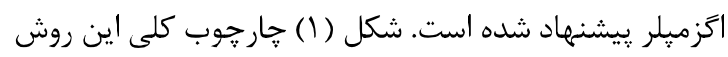

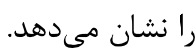

دستلبند دشوارى و استخراجگر تركيبى قسمتهاى

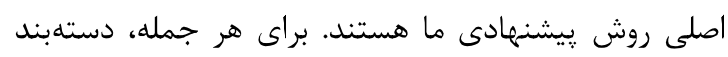

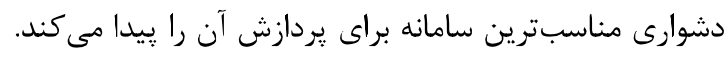

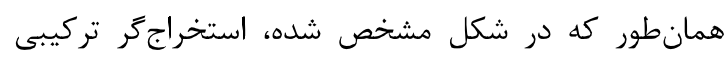

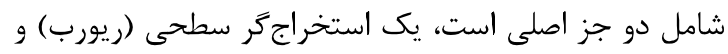

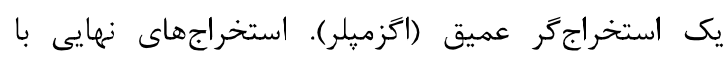

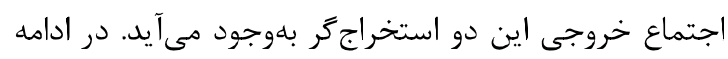

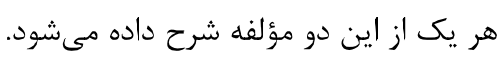

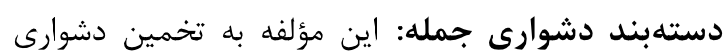

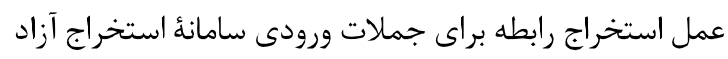
اطلاعات تمركز دارد. هدف اين مؤلفه اين است كه إتهات جمله

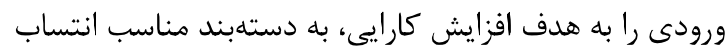

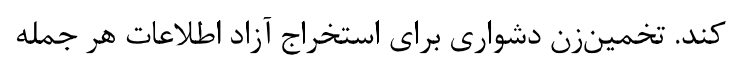


[36,37. از ابزار وكا' براى ييادهسازى ركرسيون لجستيك

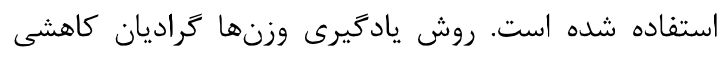

ويزَىهاى عميق نسبت به ويزَكىهاى سطحى

مىتواند دقت و بازخوانى را بهبود دهد؛ اما سرعت استخراج

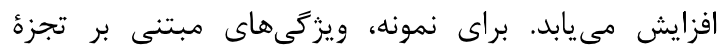

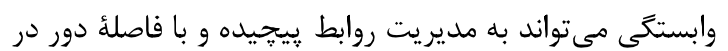

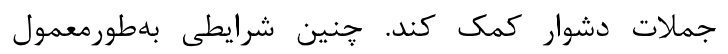

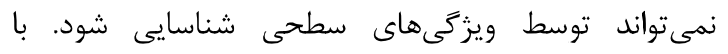

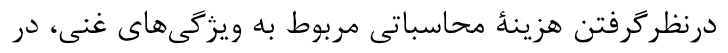

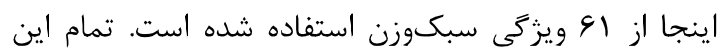

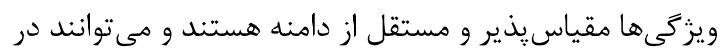

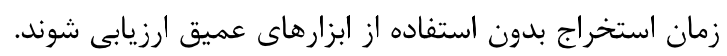

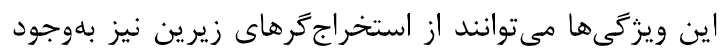

ويزگى هاى مختلفى براى دستهبند دشوارى در نظر

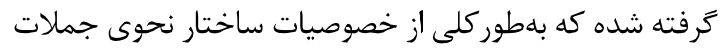

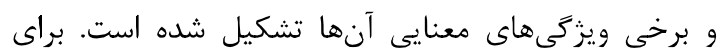

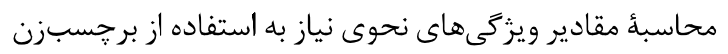

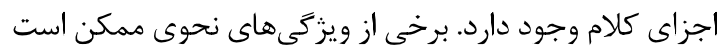

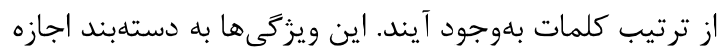

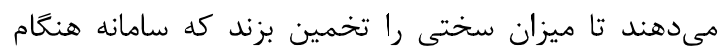

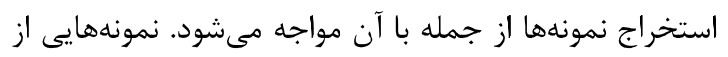

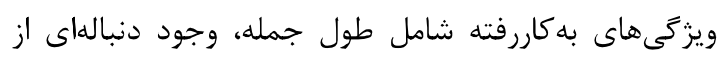

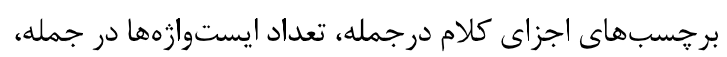

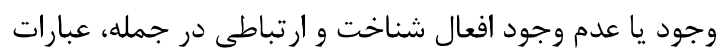

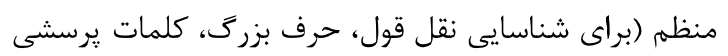

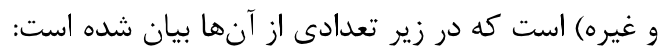

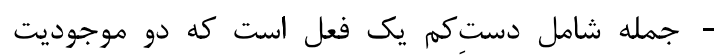
اسمى در طرفين آن قرار دارند. مانند:

A suicide car bomber attacked Iraq's largest newspaper.

- جمله شامل دستِكم يك فعل است كه دو موجوديت

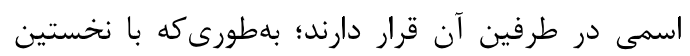

Calcium prevents osteoporosis.

$$
\text { موجوديت اسمى شروع مىشود؛ مانند: }
$$

- - جمله شامل ضماير which، whot Chicago, which is located in Illinois has three million residents.

\footnotetext{
${ }^{1}$ https://www.cs.waikato.ac.nz/ml/weka/
}

خصوصيات داراى مقادير مبناى دو باشند. يك ويزگى كه تنها داراى مقادير صفر يا يك باشد يك تابع شاخص نام دارئ دارد.

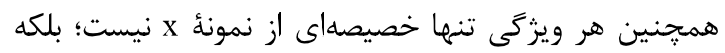

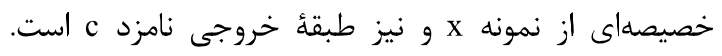

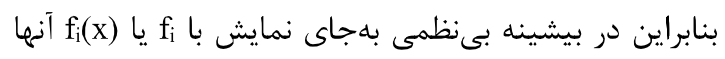

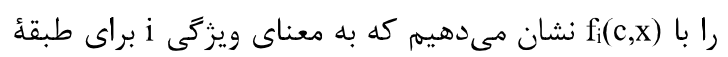

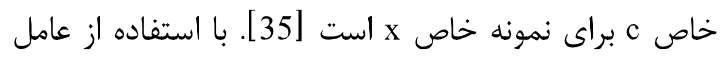

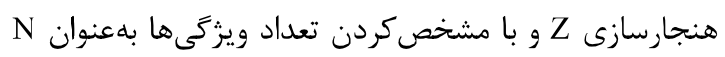

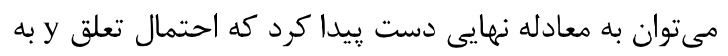

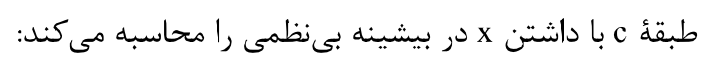

$$
P(c \mid x)=\frac{1}{Z} \exp \left(\sum_{i=1}^{N} w_{i} f_{i}(c . x)\right)
$$

مسأله مورد توجه دستهبند، اين است كه كدام استخراجكر بايد

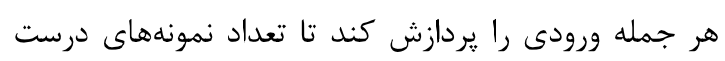

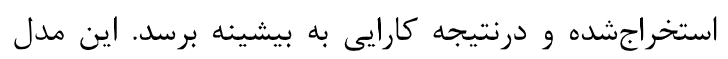

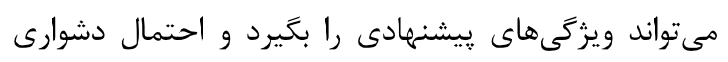

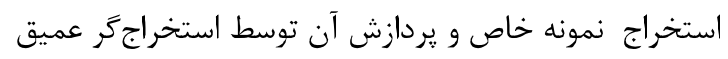

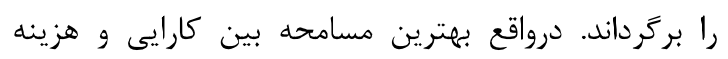

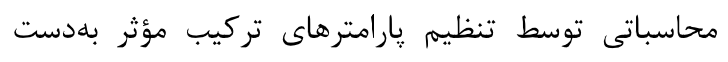

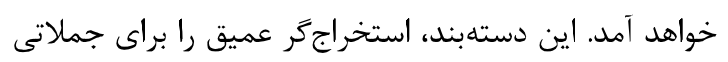

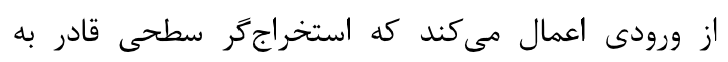

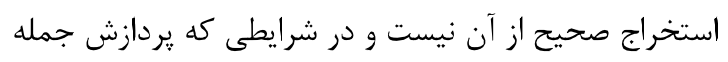

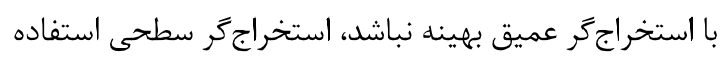

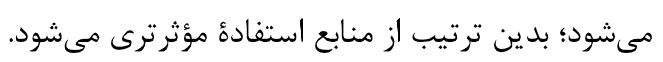

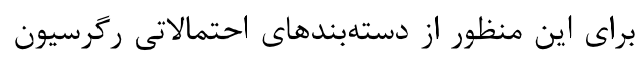

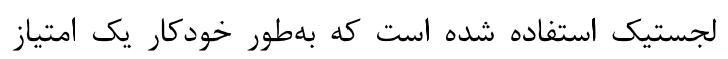
دشوارى براى هر جمله ورودى انتساب شود. ركرسيون

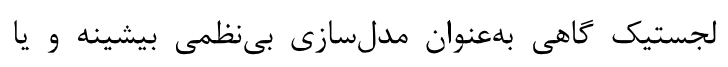
MaxEnt

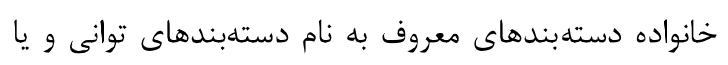

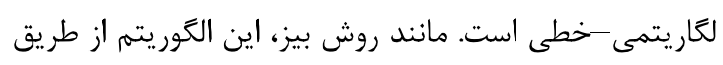

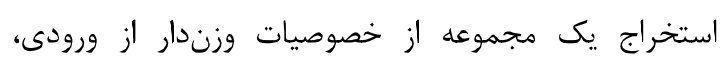

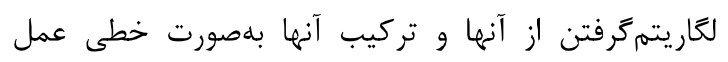

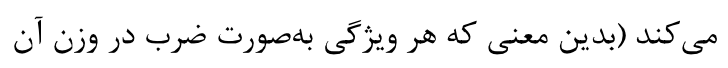

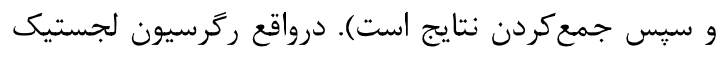

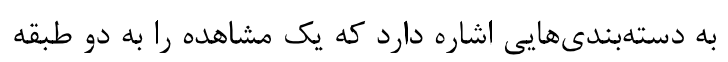

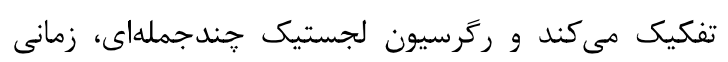

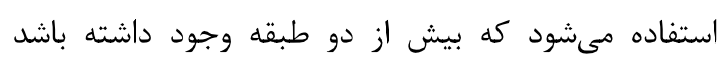


در اين مؤلفه تركيبى از ريورب بهعنوان استخراجگر

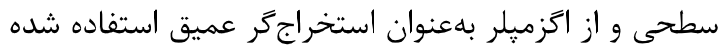

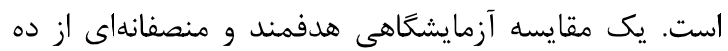
رويكرد اخير در [13] و [30] انجام شده است. مطابق اين يزوهش، ريورب سريعترين روش سطحى است كه براساس تطبيق الكَوها روى برجسبهاى رئرين اجزاى كلام كار مى كند.

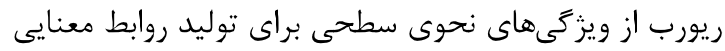

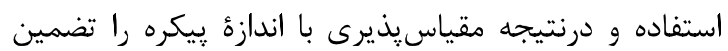
مى كند.

SONEX

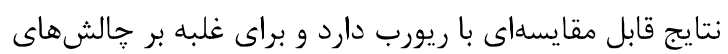

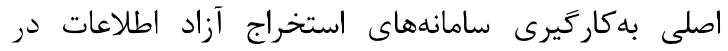

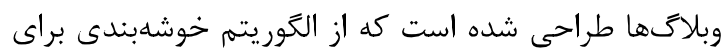

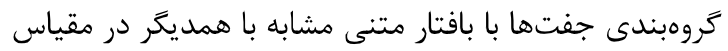

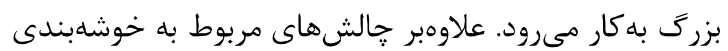

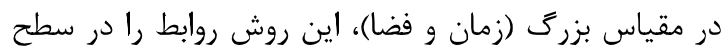

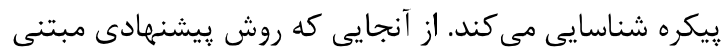

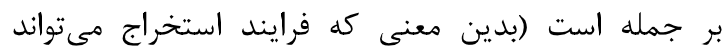

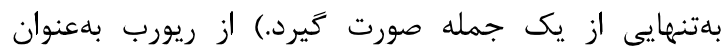

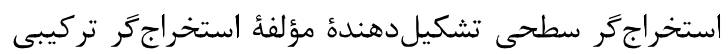

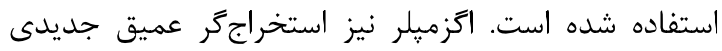

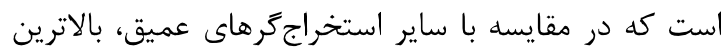

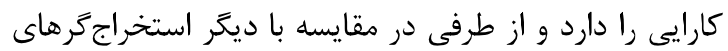

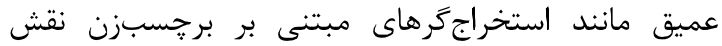

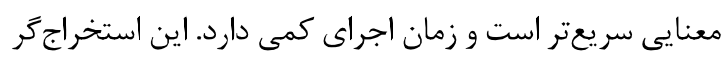

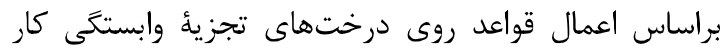

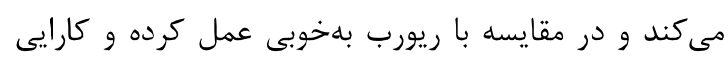

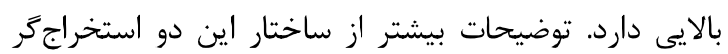

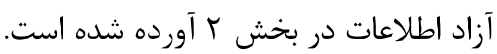

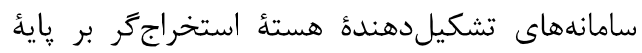

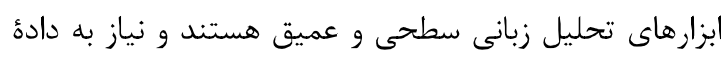

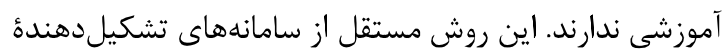

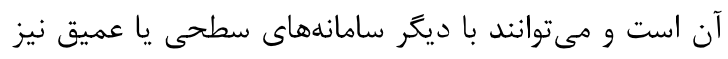
طراحى شوند.

ايده اوليهاى از اين روش براساس دو بارامتر تركيب:

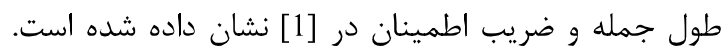

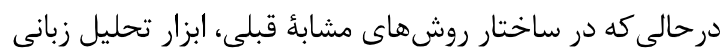

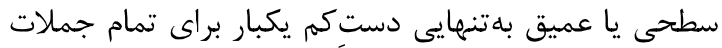

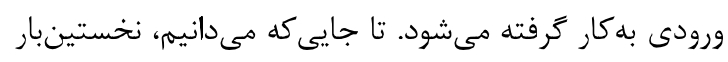

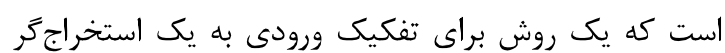

جمله شامل دستكم يك فعل است كه دو موجوديت

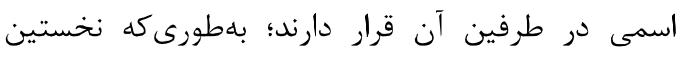
موجوديت اسمى، اسم خاص است؛ مانند:

Barack Obama was elected as president.

- جمله شامل دستِكم يك فعل است كه دو موجوديت اسمى

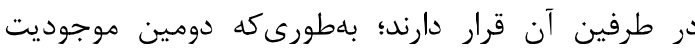
اسمى، اسم خاص است؛ مانند:

Google acquired YouTube in 2006.

- جمله شامل دستكم يك فعل است كه دو موجوديت

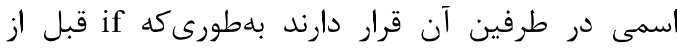
نخستين موجوديت وجود دارد؛ مانند:

If Trump wins the election, the House and the Senate will

definitely be in Republican hands - طول جمله بزرگتر از • ا است؛ مانند:

John McCain fought hard against Barak Obama, but finally lost the election.

- جمله شامل دستِكم دو موجوديت اسمى است و بعد از دومين موجوديت اسمى فعل وجود دارد؛ مانند:

After winning the Superbowl, the Saints are now the top dogs of the NFL.

- ' جمله شامل افعال ارتباطاتى ' است؛ مانند:

Early astronomers believed that the earth is the of the universe.

- تعداد ضماير نسبى `در جمله يك يا بيشتر است؛ مانند: A federal judge said that Trump does not have the right to block

people from following his Twitter posts.

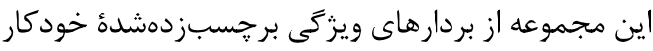
بهنوان ورودى به دستهبند ركرسيون لجستيك به برار

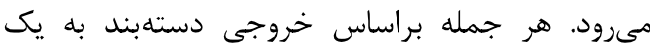
استخراجزر ارسال مىشود.

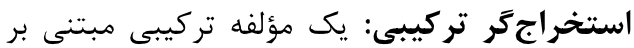
استخراجزَهاى سطحى و عميق است كه به استخراج بهينه

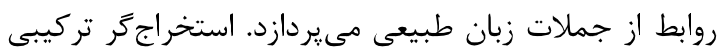

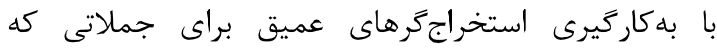
استخراجرهاى سطحى قادر به استخراج صحيح از آنهاي نيستند و يا يردازش آنها توسط استخراجگرهاى عميق بهرئ بهرينه نمىباشد، قادر به تخصيص بهتر منابع محاسباتى و حداقل بردئل

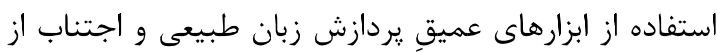

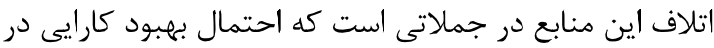
آنها كمم است. اين مؤلفه از زمان موجود، استفاده مؤثر مى كند إند و مقياس يذيرى را افزايش مى موهد.

${ }^{1}$ communication

${ }^{2}$ relative pronouns 
با فراهمكرن برجسب هاى قابل استفاده مجدد كه انعطافيذير

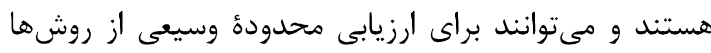
به كار روند، كاهش دهد [30].

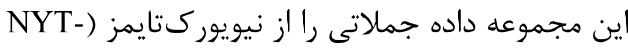

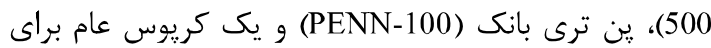
وب (WEB-500) بوشش مى دهد. WEB-500 شامل يانصد

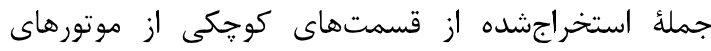
جستجو است. اين جملات اغلب ناقص بوده و از نظر كرامرى نادرست هستند و קالشهاى متون وب را بلهخوبى نشان مى دهند. NYT-500 نيز شامل بانصد جمله است كه در آن آن جملات منفردى را از متون رسمى و متونى از بِيكرة نيويورى تايمز كه بهخوبى نوشته شدهاند، نشان مى ندهد

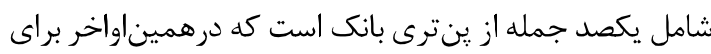

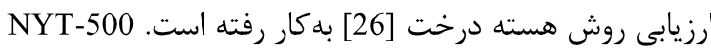

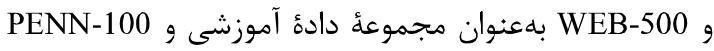
بهنوان مجموعه داده آزمايش به كار رفته است. دادههاى طلايى شامل مجموعهاى از جملاتى است كه برجسب دشوار يا آسان دارند. اين مجموعه داده بلصورت

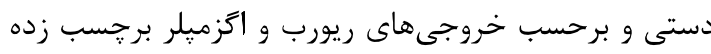

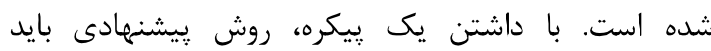

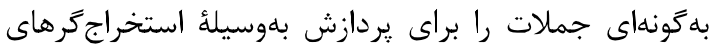

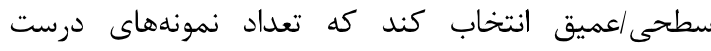
استخراجشده به بيشينه برسد. بهعبارت ديخر آن استخراجگرى

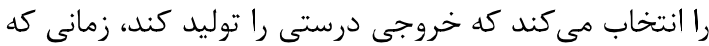

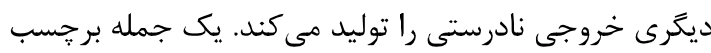

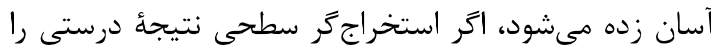
توليد كند. در شرايطى كه استخر اجزر سطحى نتيجهُ نادرستى

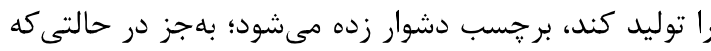
استخراجكر عميق نيز نتايج نادرستى را توليد كند. يكى جمله

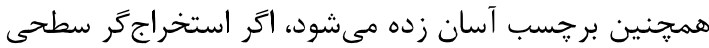

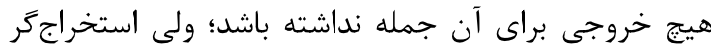

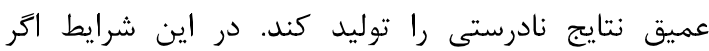

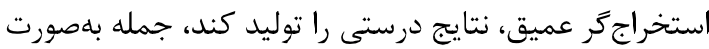

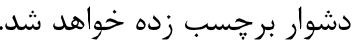
ارزيابى ما روى استخراج نمونههاى رابطه در سطح

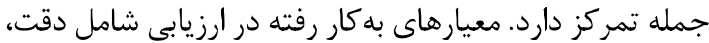
بازخوانى و معيار-f است. دقت بهصورت نسبت تعداد اردار نمونههاى درست استخراجشده به تعداد كل نمونههاى استخراجشده تعريف مىشود. بازخوانى نيز نسبت تعداد

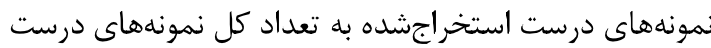

مناسب، بلمنظور دستيابى به كارايى بالا طراحى شده است.

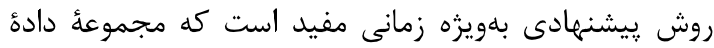

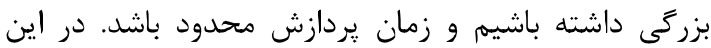

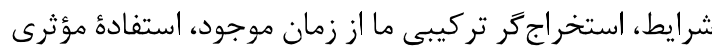
و بهترين الكوريتم را بر اساس زمان محاسباتى موجود اجرا

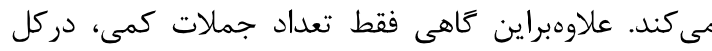

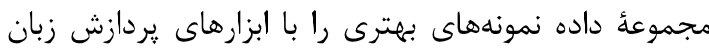

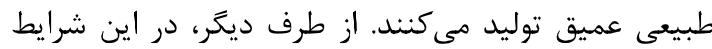

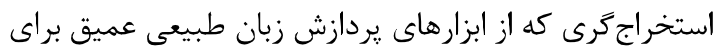
كل ورودىها بهره مي

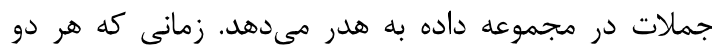

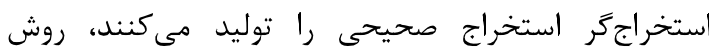
بيشنهادى، استخراجرَ سطحى را ترجيح خواهد داد واد و بنابراين كارايى بهبون مىيابد.

\section{ه- ن - نتايج آزمايشها}

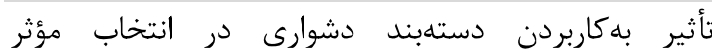

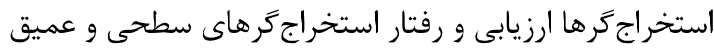

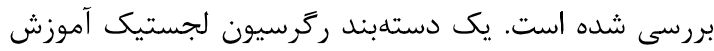

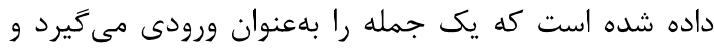

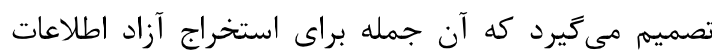

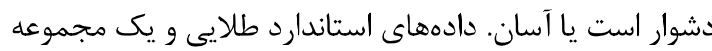
از ويزكى ها براى آموزش دستهبند دشوارى مورد نياز است.

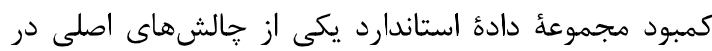

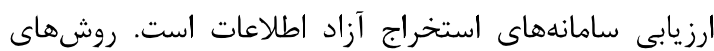

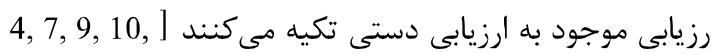
[12, 21, 23, 26, 38 مقياسيذير نيستند. تركيب مجموعه دادهاى موجود و ايجاد

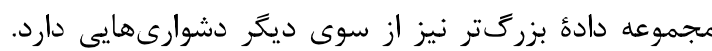

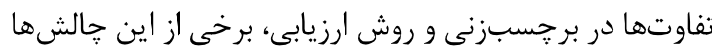

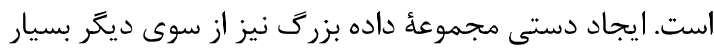

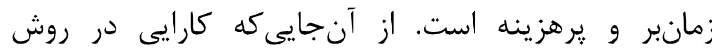

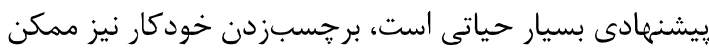
است، منجر به دقت و بازخوانى بهنسبه يايين شود.

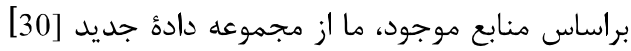
كه بلهورت دستى برجسبزده شده است، استفاده كرديم.

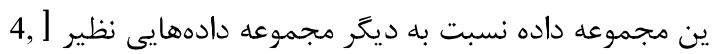
[7, 9, 10, 12, 21, 23, 26, 38 مجموعه داده سعى مى كند تا مشكلات مربوط به كمبود

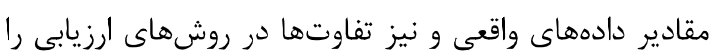


شكل (r) نمودار معيار-f fا براى هر كدام از روشها

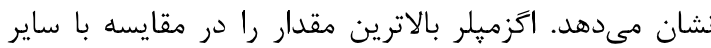
روشها دارد. اين بهطور عمده به اين دليل بازخوانى بهنسبه

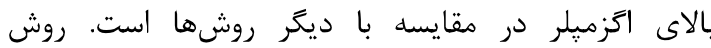

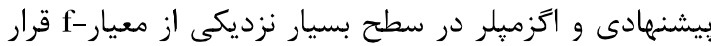
دارند. اين نشان مى دهد كه روش بيشنهادى دست كم به خوبى استخراجگر عميق تشكيلدهندهاش است. ريورب، بازخوانى

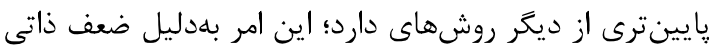
ابزارهاى سطحى در شناسايى نمونههاى روابط است كه منجر

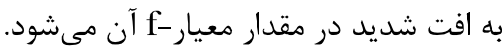

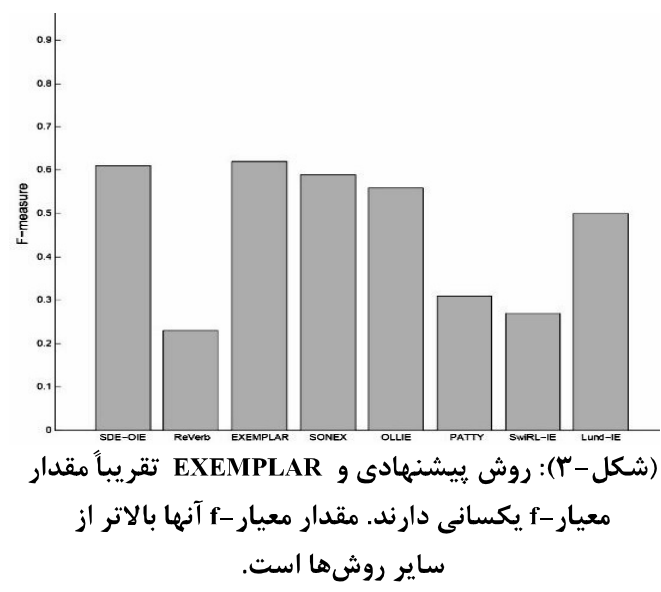

(Figure-3) :Proposed method and EXEMPLAR have almost the same F-measure. Their F-measure is better than the others.

نتايج آزمايشها اثبات مىكند كه تلفيق مناسبى از

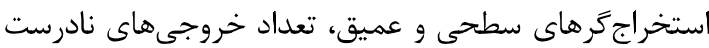

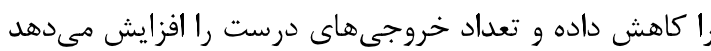

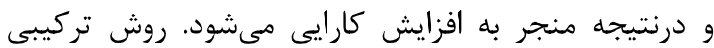

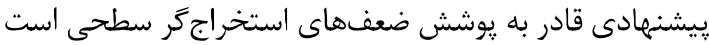

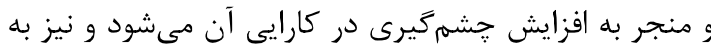

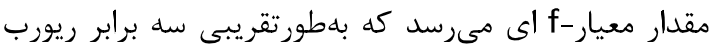
زمان محاسباتى براى انواع مختلف استخراجگرها تغيير

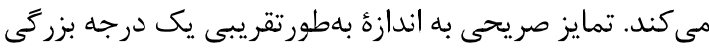

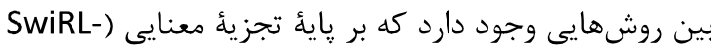

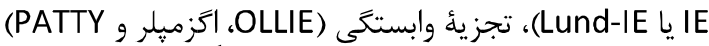

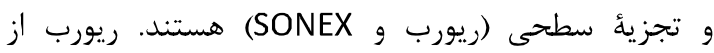
آنجايى كه از الخوهاى سطحى استفاده مى كند سريعترين روش است و بر هيج ابزار عميقى تكيه ندارد. همانطور كه نتايج نشان مىدهد، استخراجگرهاى عميق بلهورمعمول هزينئ محاسباتى بالايى دارند. دركل، هر جه استخراجئر استر عميقتر باشد، زمان محاسباتىاش بيشتر است.
تعريف مىشود. معيار - نيز متوسط دقت و بازخوانى را نشان مى دهد [1]

نمونههاى رابطه با مقادير امتيازهاى مساوى يا بزرگتر

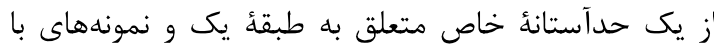
مقادير امتيازهاى كمتر از آن حد آستانه متعلق به طبقه صفر در نظر گرفته شدهاند. مقادير مختلف امتيازهاى ركرسيون لجستيك بررسى و مشاهده شد كه حد امتياز ع/ • بالاترين

$$
\text { دقت را بهوجود مى آورد. }
$$

نمودار شكل (r) دقت و بازخوانى هر يك از روشها را نشان مىدهد. يك تفاوت جزيى بين دقت روش يِيشنهادى و

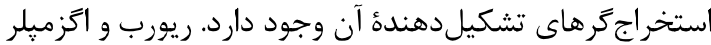
دقت بهنسبه بالايى را بهدليل طراحى الخوهاى بهنسبه مناسب براى استخراج رابطه دارند. دقت روش ييشنهادى بالاتر از دقت ريورب و اتزميلر

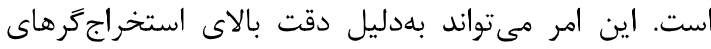

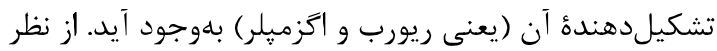
دقت، سانكس از ديخر روشها بهتر است از آنجايى كه طراحى مبتنى بر الگو آن قادر به شناسايى صحيح گَزارههاى بهوجود روسي

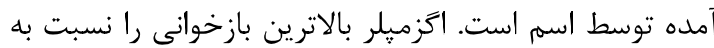

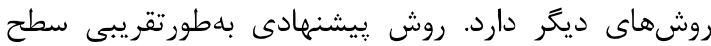

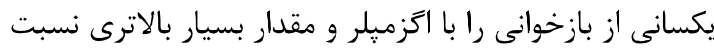

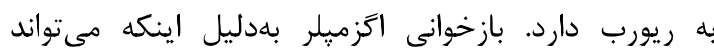
نمونههاى درست بيشترى را شناسايى كند زياد است بلهويزه آنهايى كه شامل كزارههايى از فعل +اسم هستند.

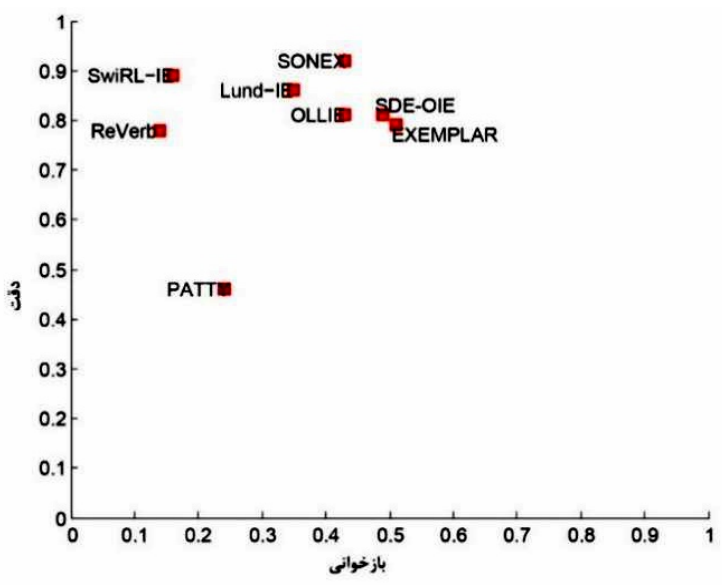

$$
\begin{aligned}
& \text { (شكل -r): روش يِيشنهادى بالاترين دقت را نسبت به } \\
& \text { استخراج كرهاى تشكيل دهندهاش و مقدار بازخوانى }
\end{aligned}
$$

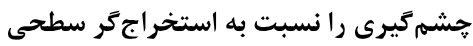

$$
\begin{aligned}
& \text { تشكيل دهندهاش دارد. }
\end{aligned}
$$

(Figure-2): Proposed approach achieves higher precision than its underlying Open IE systems, and higher recall than ReVerb. 


\section{9- نتيجه كيرى و كارهاى آينده}

هدف روش بيشنهادى اين است كه بتواند به دقت بالا در

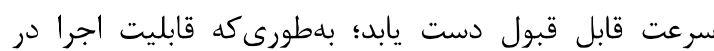

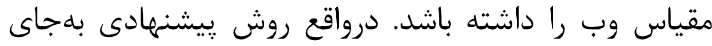

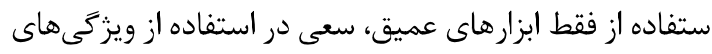

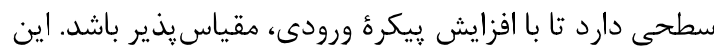
مقاله روشى جديد را براى تخمين خودكار دشوارى جملات

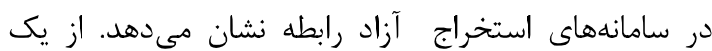

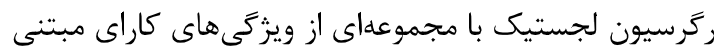
بر جمله براى تلفيق قدرت سامانه استخراج آزاد اطلاعات إنات

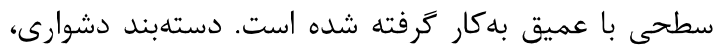

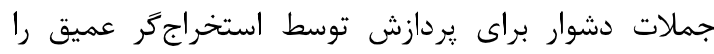

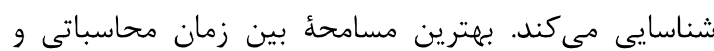
معيار-f شناسايى مىشود. نتايج آزمايشها نشان مى دهد كه مهان

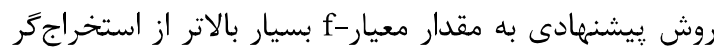

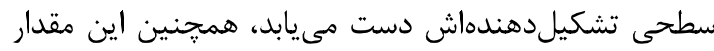
بهورتقريبى با استخراجكر عميق تشكيلدهندهاش يكان يكسان

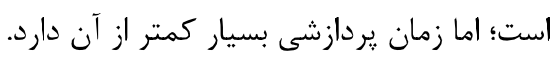

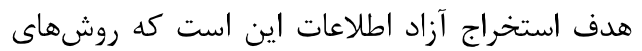

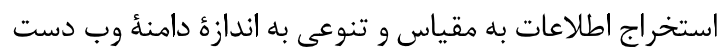

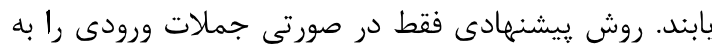

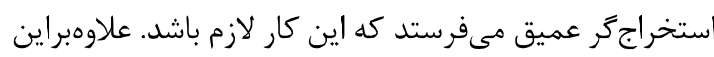

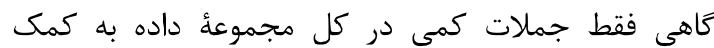

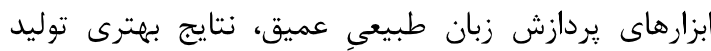

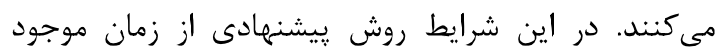

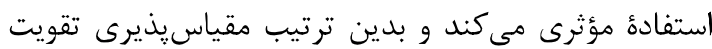

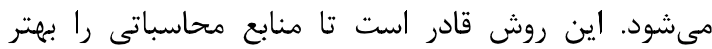

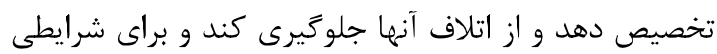

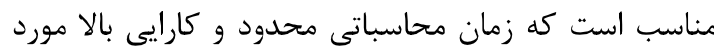

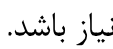

اين روش مىتواند بلخوبى به مسأله جند كلاسه تبديل

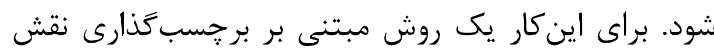

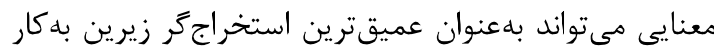

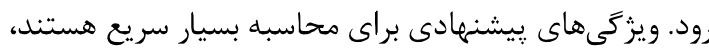

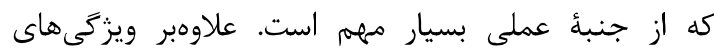

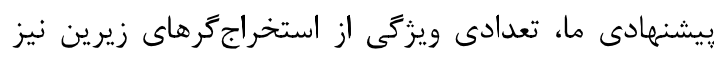

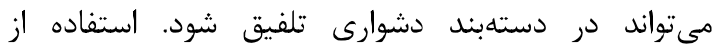

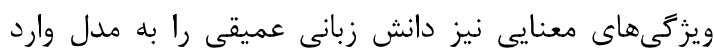
كرده اما هزينهُ زمان در آنها زياد است.
در مدت زمانى يكسان، استخراجترهاى سطحى

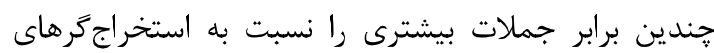

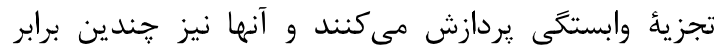

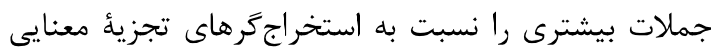
يردازش مىكنند. روش يِيشنهادى از زمان موجود، استفادئ

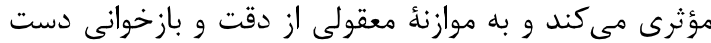

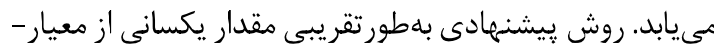

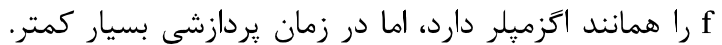

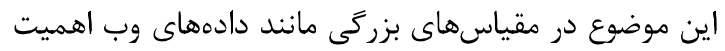

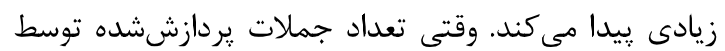

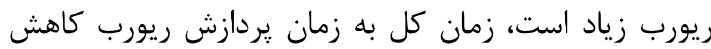

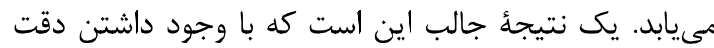

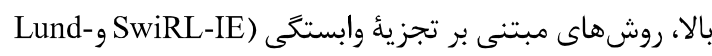

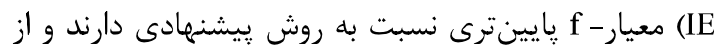

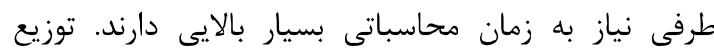

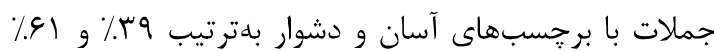

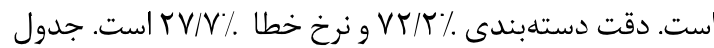

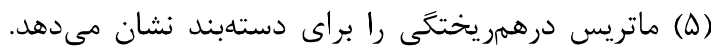

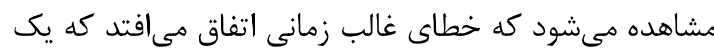

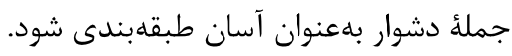

(جدول - r): زمان محاسباتى(ثانيه) براى هر رويكرد (Table-3): Computing time (per second) for each method.

\begin{tabular}{|c|c|}
\hline 0.38 & ReVerb \\
\hline 0.02 & EXEMPLAR \\
\hline 0.62 & SONEX \\
\hline 0.04 & OLLIE \\
\hline 0.14 & PATTY \\
\hline 0.66 & SwiRL-IE \\
\hline 2.17 & Lund-IE \\
\hline 5.21 & \\
\hline
\end{tabular}

(جدول - P): ماتريس درهمريختكى مربوط به كارايى دستهبند (Table-4): The confusion matrix for the performance of the

\begin{tabular}{|c|c|c|}
\hline \multicolumn{3}{|c|}{ difficulty classifier } \\
\hline دشوار & آسان & دادهاى طلايى /دادههاى \\
\hline 0.25 & 0.66 & آسان \\
\hline 0.75 & 0.33 & دشوار \\
\hline
\end{tabular}


Methods in Natural Language Process-ing, 2011, pp. 1535-1545.

[13]F. Mesquita, J. Schmidek, and D. Barbosa, "Effectiveness and efficiency of open relation extraction," in Proceedings of the 2013 Conference on Empirical Methods in Natural Language Processing, vol. 500, pp. 447-457, 2013.

[14] M. Banko, M. J. Cafarella, S. Soderland, M. Broadhead, and O. Etzioni, "Open information extraction for the web," in IJCAI, 2007, pp. 2670 2676.

[15] Y. Merhav, F. Mesquita, D. Barbosa, W. G. Yee, and O. Frieder, "Extracting information networks from the blogosphere," ACM Transactions on the Web (TWEB), vol. 6, p. 11, 2012.

[16]L. Qiu and Y. Zhang, "Zore: A syntax-based system for chinese open relation extraction," in Proceedings of EMNLP, 2014.

[17] Y.-H. Tseng, L.-H. Lee, S.-Y. Lin, B.-S. Liao, M.J. Liu, H.-H. Chen, O. Etzioni, and A. Fader, "Chinese open relation extraction for knowledge acquisition," EACL 2014, p. 12, 2014.

[18]P. Gamallo and M. Garcia, "Multilingual open information extraction," in Portuguese Conference on Artificial Intelligence, 2015, pp. 711722.

[19]C. Castella Xavier, S. de Lima, V. Lúcia, and M. Souza, "Open information extraction based on lexical-syntactic patterns," in Intelligent Systems (BRACIS), 2013 Brazilian Conference on, 2013, pp. 189-194.

[20]P. Cimiano , and J. Wenderoth, "Automatically learning qualia structures from the web," in Proceedings of the ACL-SIGLEX workshop on deep lexical acquisition, 2005, pp. 28-37.

[21] M. Schmitz, R. Bart, S. Soderland, and O. Etzioni, "Open language learning for information extraction," in Proceedings of the 2012 Joint Conference on Empirical Methods in Natural Language Processing and Computational Natural Language Learning, 2012, pp. 523-534.

[22]N. Nakashole, G. Weikum, and F. Suchanek, "PATTY: a taxonomy of relational patterns with semantic types," in Proceedings of the 2012 Joint Conference on Empirical Methods in Natural Language Processing and Computational Natural Language Learning, 2012, pp. 1135-1145.

[23]H. Bast and E. Haussmann, "Open information extraction via contextual sentence decomposition," in Semantic Computing (ICSC), 2013 IEEE Seventh International Conference on, 2013, pp. 154-159.

[24]H. Bast and E. Haussmann, "More informative open information extraction via simple inference," in Advances in information retrieval, ed: Springer, 2014, pp. 585-590.

\section{7- References}

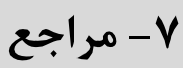

[1] V. Reshadat, M. Hoorali, and H. Faili, "A Hybrid Method for Open Information Extraction Based on Shallow and Deep Linguistic Analysis," Interdisciplinary Information Sciences, vol. 22, pp. 87 100, 2016.

[2] J. Piskorski and R. Yangarber, "Information extraction: Past, present and future," in Multisource, Multilingual Information Extraction and Summarization, ed: Springer, 2013, pp. 23-49.

$$
\begin{aligned}
& \text { [r] نيما مولايى، حسين شيرازى. روش يِيشنهادى براى }
\end{aligned}
$$

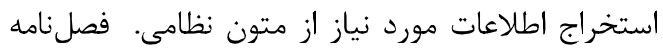

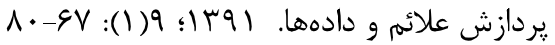

[3] N. mollaei, A. Abdolahzadeh, H. A. Shirazi, new approach to extract the required information from military documents. JSDP. 2012; 9 (1): pp.67-80

[4] L. Del Corro and R. Gemulla, "ClausIE: clausebased open information extraction," in Proceedings of the 22nd international conference on World Wide Web, 2013, pp. 355-366.

[5] O. Etzioni, M. Banko, S. Soderland, and D. S. Weld, "Open information extraction from the web," Communications of the ACM, vol. 51, pp. 68-74, 2008.

[6] O. Etzioni, A. Fader, J. Christensen, S. Soderland, and M. Mausam, "Open Information Extraction: The Second Generation," in IJCAI, 2011, pp. 3-10.

[7] F. Wu and D. S. Weld, "Open information extraction using Wikipedia," in Proceedings of the 48th Annual Meeting of the Association for Computational Linguistics, 2010, pp. 118-127.

[8] A. Akbik and J. Broß, "Wanderlust: Extracting semantic relations from natural language text using dependency grammar patterns," in $W W W$ Workshop, 2009

[9] A. Akbik ,and A. Löser, "Kraken: $\mathrm{N}$-ary facts in open information extraction," in Proceedings of the Joint Workshop on Automatic Knowledge Base Construction and Web-scale Knowledge Extraction, 2012, pp. 52-56.

[10]P. Gamallo, M. Garcia, and S. Fernández-Lanza "Dependency-based open information extraction," in Proceedings of the Joint Workshop on Unsupervised and Semi-Supervised Learning in NLP, 2012, pp. 10-18.

[11]V. Tablan, K. Bontcheva, D. Maynard, and H. Cunningham, "Ollie: on-line learning for information extraction," in Proceedings of the HLT-NAACL 2003 workshop on Software engineering and architecture of language techno-logy systems-Volume 8, 2003, pp. 17-24.

[12]A. Fader, S. Soderland, and O. Etzioni, "Identifying relations for open information extraction," in Proceedings of the Conference on Empirical 


$$
\begin{aligned}
& \text { بوده و زمينه علاقهمندى وى هوش مصنوعى، يردازش زبان }
\end{aligned}
$$

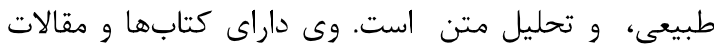

$$
\begin{aligned}
& \text { بسيارى در نشريات معتبر بينالمللى است. }
\end{aligned}
$$

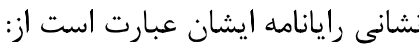

\section{hfaili@ut.ac.ir}

[25] H. Lin, Y. Wang, P. Zhang, W. Wang, Y. Yue, and Z. Lin, "A Rule Based Open Information Extraction Method Using Cascaded Finite-State Transducer," in Pacific-Asia Conference on Knowledge Discovery and Data Mining, 2016, pp. 325-337.

[26]Y. Xu, M.-Y. Kim, K. Quinn, R. Goebel, and D. Barbosa, "Open Information Extraction with Tree Kernels," in HLT-NAACL, 2013, pp. 868-877.

[27]J. Christensen, S. Soderland, and O. Etzioni, "An analysis of open information extraction based on semantic role labeling," in Proceedings of the sixth international conference on Knowledge capture, 2011, pp. 113-120.

[28] V. Punyakanok, D. Roth, and W.-t. Yih, "The importance of syntactic parsing and inference in semantic role labeling," Computational Linguistics, vol. 34, pp. 257-287, 2008.

[29]R. Johansson and P. Nugues, "The effect of syntactic representation on semantic role labeling," in Proceedings

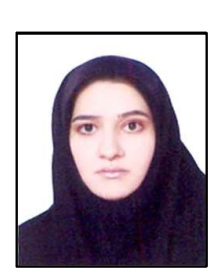

$$
\begin{aligned}
& \text { وحيده رشادت دوره كارشناسى و ارشد }
\end{aligned}
$$

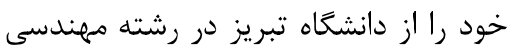

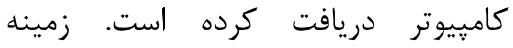

$$
\begin{aligned}
& \text { علاقهمندى وى بردازش زبان طبيعى بهويزه }
\end{aligned}
$$

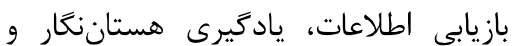

$$
\begin{aligned}
& \text { استخراج اطلاعات است. } \\
& \text { نشانى رايانامةٔ ايشان عبارت است ازئ }
\end{aligned}
$$

com.v.reshadat@gmail.com

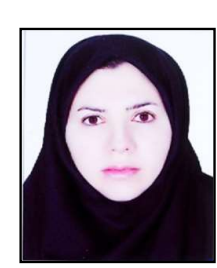

مريم حورعلى دوره كارشناسى خود را از

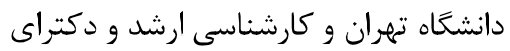

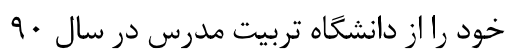
دريافت كرده است. ايشان همماكنون استاديار دانشكاه صنعتى مالك اشتر بوده و

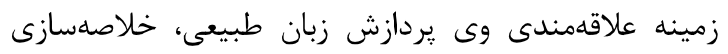
متن، يادكيرى هستاننغار و تحليل متن است.

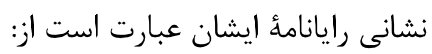
mhourali@mut.ac.ir

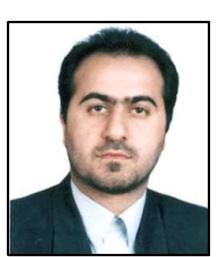

